\title{
Results from Newberry Volcano EGS Demonstration, 2010-2014
}

\author{
Trenton T. Cladouhos, Susan Petty, Michael W. Swyer, Matthew E. Uddenberg, Kyla Grasso, Yini Nordin \\ AltaRock Energy, 4010 Stone Way North, Suite 400, Seattle WA 98103 \\ Corresponding Author: tcladouhos@altarockenergy.com
}

Keywords: EGS, enhanced geothermal system, Newberry, stimulation, microseismicity, hydroshearing

\begin{abstract}
The Newberry Volcano EGS Demonstration is a 5 year field project designed to demonstrate recent technological advances for engineered geothermal systems (EGS) development. Advances in reservoir stimulation, diverter, and monitoring are being tested in a hot $\left(>300^{\circ} \mathrm{C}\right.$ ), dry well (NWG 55-29) drilled in 2008. These technologies could significantly reduce the cost of electrical power generation from geothermal resources. The project, funded in part by the Department of Energy, began in 2010 with two years of permitting, technical planning, and development of a project-specific Induced Seismicity Mitigation Plan (ISMP). Well stimulation carried out in 2012 indicated that casing repairs were needed; confirmed by further wellbore logging and analysis in 2013. Repairs were completed in August 2014, and the well was re-stimulated in the fall. 9,500 $\mathrm{m}^{3}$ (2.5 million gallons) of groundwater were injected at a maximum wellhead pressure of 195 bar (2850 psi) over 4 weeks of hydraulic stimulation. Injectivity changes, thermal profiles and seismicity indicate that fracture permeability in well NWG 55-29 was enhanced. The fifteen-station microseismic array (MSA) located 398 events in 2014, ranging in magnitude from M 0 to M 2.26. Temperature logs run after injection of thermally-degradable zonal isolation material (TZIM) showed that at least two flow zones were blocked and one or two new zones opened because of the injected TZIM. Break-down products of TZIM were detected in flow-back fluids, indicating that the material degraded as predicted. This work demonstrates the viability of large-volume low-pressure stimulation coupled with non-mechanical diverter technology and microseismic monitoring for reservoir mapping.
\end{abstract}

\section{INTRODUCTION}

Newberry Volcano is a shield volcano located in central Oregon, about $35 \mathrm{~km}$ south of the city of Bend and $50 \mathrm{~km}$ east of the crest of the Cascade Range. The Newberry EGS Demonstration is being conducted on federal geothermal leases and National Forest Service lands located in the Deschutes National Forest, adjacent to Newberry National Volcanic Monument (NNVM) (Figure 1). Since the 1970s, extensive exploration activities have been conducted in the Newberry area by public and private entities. Such exploration activities include various geoscience surveys, drilling of thermal gradient holes, slim holes, and deep, large-bore wells. In 2010,

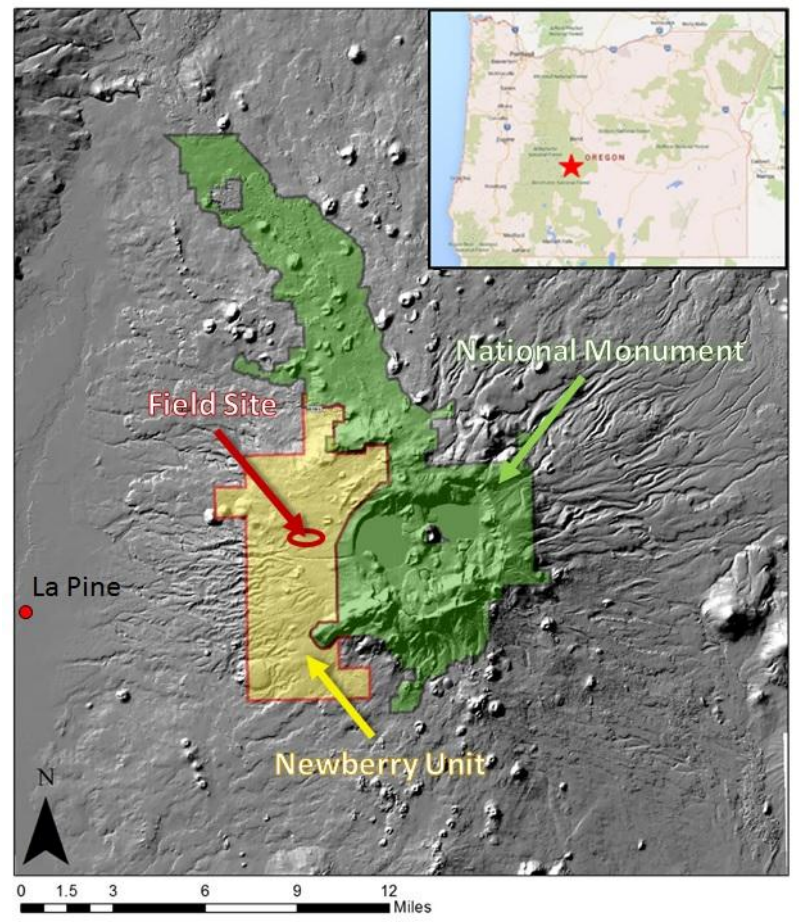

Figure 1. Map of Project Site and the Davenport Newberry Unit Area. The Unit Area comprises Federal geothermal leases administered by the BLM with Davenport Newberry Holdings, LLC designated as the Unit operator for the purposes of exploration, development and operations. 
Cladouhos et al.

AltaRock Energy, Inc. (AltaRock), in partnership with Davenport Newberry (Davenport), was awarded a U.S. Department of Energy (DOE) grant to demonstrate EGS technology at Newberry. The demonstration project consists of three Phases (Figure 2):

Phase 1: Extensive planning and permitting from 2010 to spring 2012. This included creation of public outreach campaigns, creation of the induced seismicity mitigation plan (ISMP) and planning of the stimulation program.

Phase 2: Initial stimulation of well 55-29 in 2012; 55-29 work-over and re-stimulation in 2014; drilling of 55A-29 production well and subsequent stimulation in 2015 .

Phase 3: Well interconnectivity test in 2015; power plant planning and construction (dates unknown).

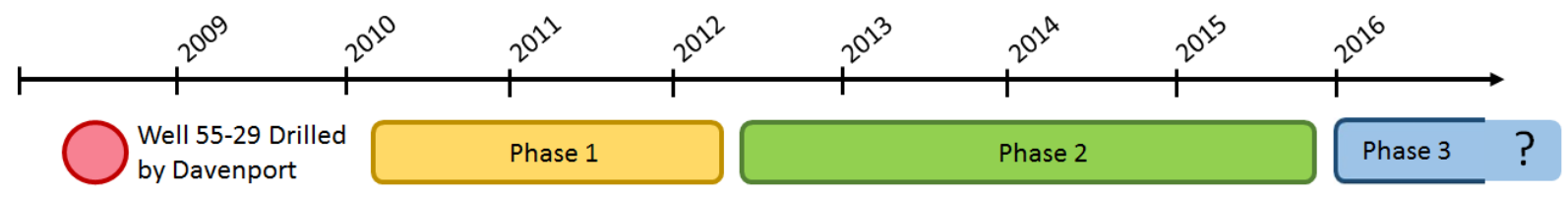

\section{Figure 2. Timeline of project phases}

The goal of this demonstration is to create a functioning Engineered Geothermal System (EGS) in a hot and impermeable volume of rock using new stimulation and characterization techniques. So far these goals have been partially accomplished. Many of the technologies and characterization methods have been verified and field tested. However, setbacks were encountered during the initial field testing. In 2012 a problem with the casing led to an ineffective stimulation and required AltaRock to run a tie-back in well 55-29 in the summer of 2014 and re-stimulation in the fall of 2014. During the 2014 stimulation a significant volume of rock was stimulated, enhancing both the permeability and the volume of the fractured reservoir at depth.

\section{EGS STIMULATION TECHNOLOGY}

\subsection{Hydroshearing}

AltaRock uses the term hydroshearing (Cladouhos et al., 2009) to describe the process of injecting water at moderate pressure, below the minimum principle stress $\left(\mathrm{S}_{\mathrm{hmin}}\right)$, to cause existing fractures to dilate and slip in shear. A byproduct of shear-slip is the generation of seismic waves that can be used to map fracture location and size. In contrast, tensional fracturing, or hydrofracing, commonly used in the oil and gas industry requires fluid pressures well above $S_{h \min }$. After shear-slip, irregularities along the natural fracture surfaces cause the fractures to remain self-propped, creating lasting permeability enhancement. This ability to enhance permeability without the use of proppants, which may not last at high temperatures, is another benefit of hydroshearing.

It should be noted that hydroshearing is a simplified conceptual model and that real world implementation of this method will result in an array of outcomes. The non-uniform results obtained from employing hydroshearing are largely caused by the heterogeneity of the reservoir rock. For example, an existing crack may open, close or shear depending on its orientation, cohesive strength and local stresses. Thermal stresses imposed on the rock by cooling during injection may also cause tensile fractures to form. The important distinction is that in hydroshearing the stimulation equipment is designed to keep the down hole pressure below $\mathrm{S}_{\mathrm{hmin}}$, while in hydrofracing it is designed to exceed $S_{\text {hmin }}$. Staying below $S_{\text {hmin }}$ will likely not result in formation of large $(>20 \mathrm{~m})$ scale tensile fractures.

Seismic data can be used to determine whether failure is shear or tensile. Microseismic energy recorded on a seismic network will be the result of shear failure, while tensional failure (fracking) is largely aseismic. Further while there may be some P-wave resultant from fracking there will be no S-waves, therefore S-wave arrivals can be used to confirm hydroshearing has occurred.

Another implicit assumption of EGS/hydroshearing is that microseismicity illuminates flow paths of the injected fluid that can be traced back to the injection well. However, seismicity cannot confirm connectivity within the reservoir, seismic events located away from the well could be related to fluid pressure or stress changes only.

\subsection{Induced Seismicity Mitigation Plan (ISMP)}

To quantify and mitigate the risks associated with induced seismicity at the Newberry EGS demonstration, AltaRock developed a project-specific Induced Seismicity Mitigation Plan (AltaRock, 2011; BLM, 2011) for the EGS demonstration that satisfied the requirements of the Induced Seismicity Mitigation Protocol adopted by the DOE (Majer et al., 2011). This included predicting the largest possible induced microearthquake and developing predefined thresholds of event magnitudes and ground motion accompanied by appropriate mitigation actions. The full ISMP is publically available on AltaRock's website (AltaRock, 2011) and included in the project's Environmental Assessment (BLM, 2011).

\subsection{Thermally-degradable Zonal Isolation Material (TZIM)}

The creation of EGS reservoirs has historically involved the stimulation of a single fracture set around an existing well bore. This is due to the fact that during stimulation the existing fracture with the lowest hydroshearing pressure will open when water is pumped from the surface and pressure is applied in the injection well, and other existing fractures that require a higher shear pressure are not affected (Figure 3, left). The stimulation of multiple fracture sets in a single injection well is necessary to significantly increase EGS efficiency 
Thermally-degradable Zonal Isolation Material (TZIM) are particle diverters made from a suite of materials which degrade to non-toxic soluble elements at a range of temperatures. TZIM comes in both particle and fibrous form and can be prepared in a range of sizes. By using different size particles and fibers, the particle diverter can be optimized to block primary permeable features. The material used at a specific site depends on the temperature of well and the duration that a zone needs to be blocked. Each material degrades at different rates given varying temperature conditions.

To stimulate multiple fracture sets in a single well requires hydraulic isolation of each fracture network after it has been stimulated. TZIM provides hydraulic isolation for the stimulation of multiple fractures (Petty et al., 2011). After the stimulation of the first fracture set (Figure 3, left), a pill of TZIM is mixed and pumped to temporarily seal the fracture network stimulated in the first stage from accepting additional fluid (Figure 3, center). Additional pressure is then applied to the well and a second set of fractures, which had a higher minimum hydroshearing pressure than the fractures stimulated in the previous stage, will be stimulated (Figure 3, center). After multiple fractures are stimulated injection is discontinued and the well bore is allowed to reheat to the original well temperature. This causes the diverter material to thermally degrade, leaving all fractures open for circulation and flow during the operation of the EGS reservoir (Figure right).

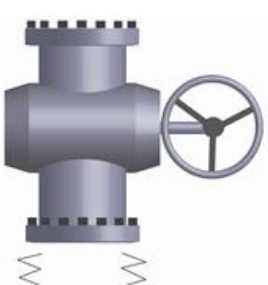

Stage 1

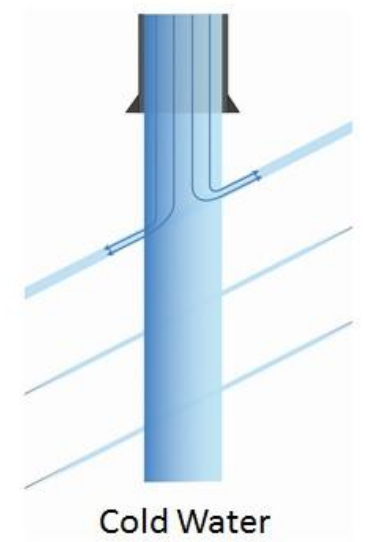

\section{Multizone Stimulation and TZIMs}
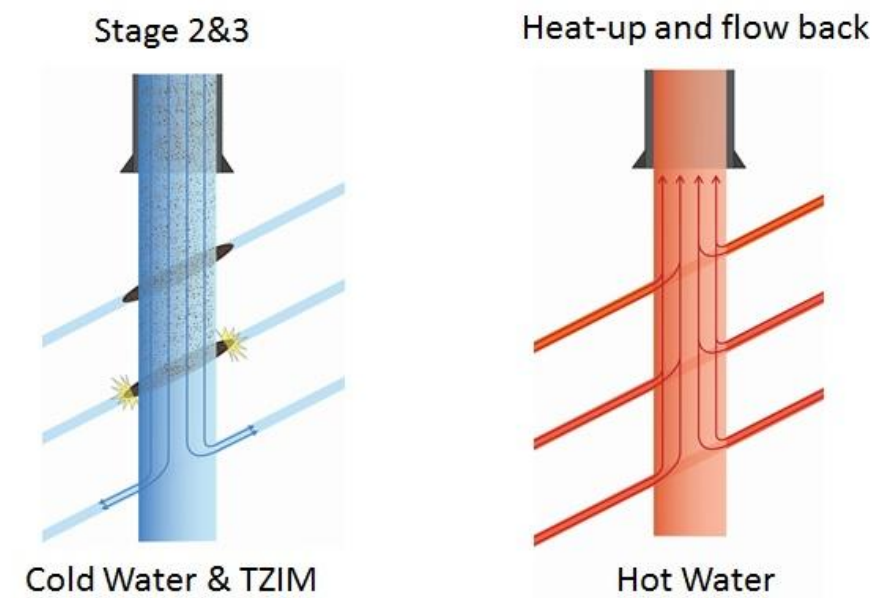

Figure 3. TZIM is the principal technology behind AltaRock's multi-zone stimulation technique. It is used to block principal permeable features so that other zones in the well can be stimulated.

\section{PHASE 1 ACTIVITIES}

Phase 1 of the Demonstration began in May 2010 and was concluded in December 2011. The team's activities, as well as those of the grant sub-recipients, included various field, laboratory and administrative studies. Field activities included: installing a temporary microseismic array (MSA), a seismic calibration study to develop a local velocity model, monitoring background seismic data, upgrading water well equipment and testing the two existing water wells, conducting a baseline injection rate test, pressure-temperature surveys, and borehole televiewer imaging. Laboratory and office studies included: development of a native state numerical reservoir model, a fracture stimulation model, developing new reservoir tracers and tracer models, and laboratory analyses of core and cuttings.

Permitting and administrative efforts included development of comprehensive plans for conducting Phase 2 activities, compiling a hydrological study of the local area, independent hydrology and seismic hazard and risk assessments, and working with the BLM, the US Forest Service (USFS) and the DOE to conduct an Environmental Assessment (EA) of project plans, and establishing an Induced Seismicity Mitigation Plan (ISMP) (BLM, 2011). A comprehensive report of Phase 1 activities and Phase 2 plans was completed in August 2011, and submitted to the DOE. The DOE convened a technical committee to perform a stage-gate review process, a prerequisite to Phase 2 activities. After revisions, the report and plans were approved by the DOE in November 2011.

Also in Phase 1, AltaRock established a comprehensive public outreach campaign to inform the public about project-related activities by conducting outreach and informational meetings in local communities, publishing project plans and independent consultant reports, and providing relevant educational materials about geothermal and EGS on multiple web sites and social media (www.facebook.com/NewberryEGS and blog.newberrygeothermal.com). The public outreach has continued throughout all project 


\section{Cladouhos et al.}

phases. Phase 1 activities and results are also discussed in Osborn et al. (2010, 2011), Cladouhos et al. (2011a, 2011b), and the EA (BLM, 2011).

\subsection{Well NGW 55-29 Characterization}

Drilling of well 55-29 began on April 13, 2008 as part of an exploration program conducted by Davenport Newberry Holding Company. The well was drilled to a measured depth of 3,067 m (10,060 ft) without encountering major loss zones. After drilling the equilibrated static bottom hole temperature (BHT) was determined to be $331{ }^{\circ} \mathrm{C}\left(628{ }^{\circ} \mathrm{F}\right)$, making this well one of the hottest exploration wells at Newberry. In 2010 AltaRock compiled existing data on well 55-29 to determine suitability for stimulation and help in the planning process. A current well schematic and lithology description for 55-29 can be seen in Figure 2.Figure 4. Current well bore schematic (see notes on 2008 and 2014 elements), lithology encountered within the bore hole, and temperature surveys within the well bore.

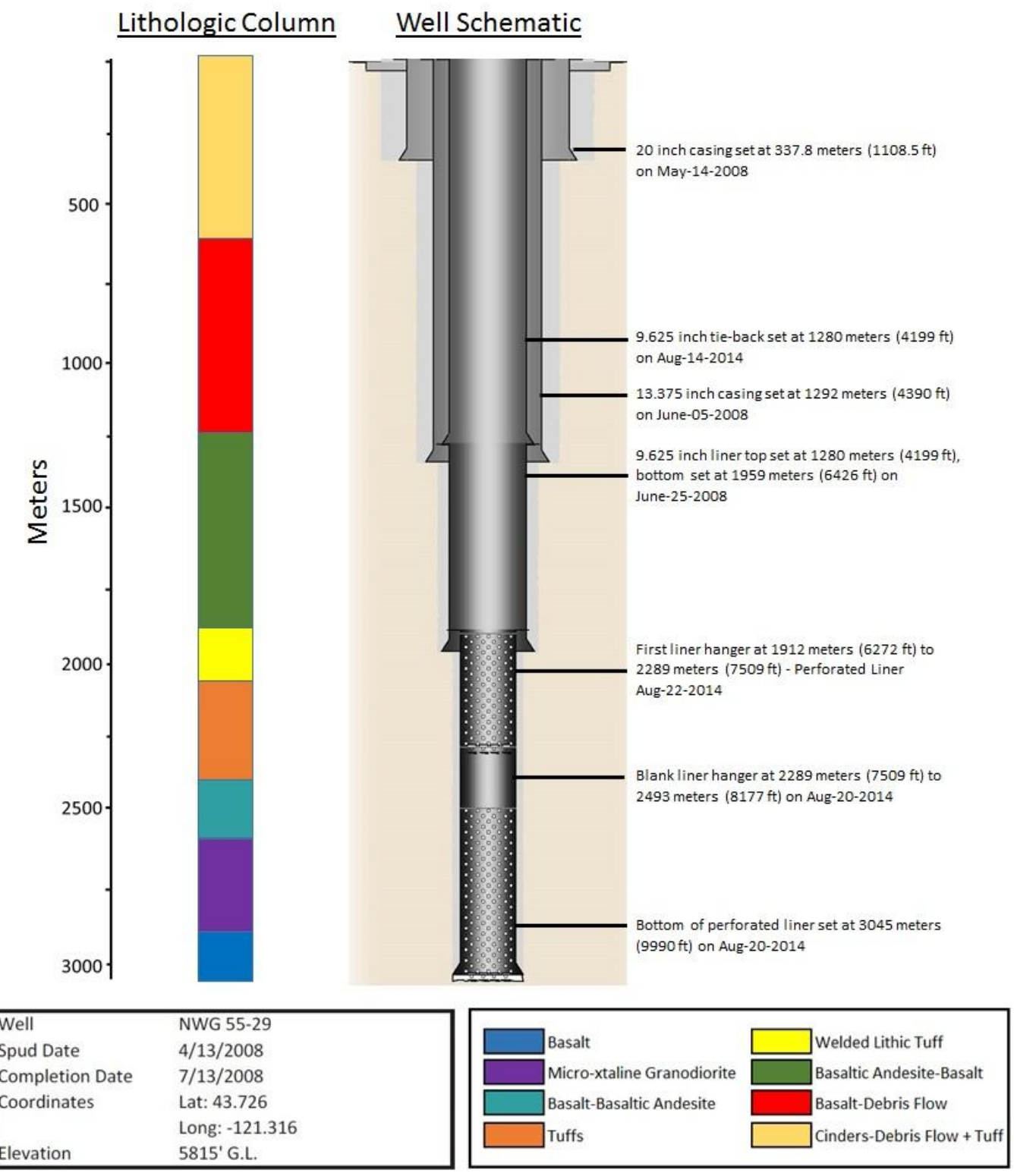

Figure 4. Current well bore schematic (see notes on 2008 and 2014 elements), lithology encountered within the bore hole, and temperature surveys within the well bore.

\subsection{Stimulation Planning}

As a part of Phase 1, several data sets were collected to characterize the rock volume around the well. Fracture, fault, stress, and seismicity data were collected by borehole televiewer (BHTV), LiDAR elevation maps, and microseismic monitoring (Cladouhos et al., 2011a,b). Well logs and cuttings from the target well (NWG 55-29) and core from a nearby core hole (USGS N-2) were analyzed to develop geothermal, geochemical, mineralogical and strength models of the rock matrix, altered zones, and fracture fillings (Osborn et al., 2011). 
In the fall of 2010 , injection testing was performed to determine a baseline: at 73 bar (1153 psi), a flow rate of $1.41 / \mathrm{s}$ (22 gpm) was achieved, indicting an injectivity of 0.02 (1/s)/bar. Next, in October 2010, NWG 55-29 was logged using a high temperature borehole televiewer (BHTV) manufactured by Advanced Logic Technology (ALT). The borehole breakouts showed a consistent azimuth indicating that the minimum horizontal stress, Shmin is oriented at $092 \pm 16.6^{\circ}$ relative to true north (Davatzes and Hickman, 2011). This azimuth of Shmin, in combination with the attitude of the majority of natural fractures revealed in the image log, are consistent with normal faulting (Figure 5). The consistency of breakout azimuth, without localized rotations, taken in combination with the extremely low rate of seismicity in the region and the weak expression of natural fractures in the image log, suggests that there has been little recent or active slip on fractures in the vicinity of the well (Davatzes and Hickman, 2011; Cladouhos et al., 2011).
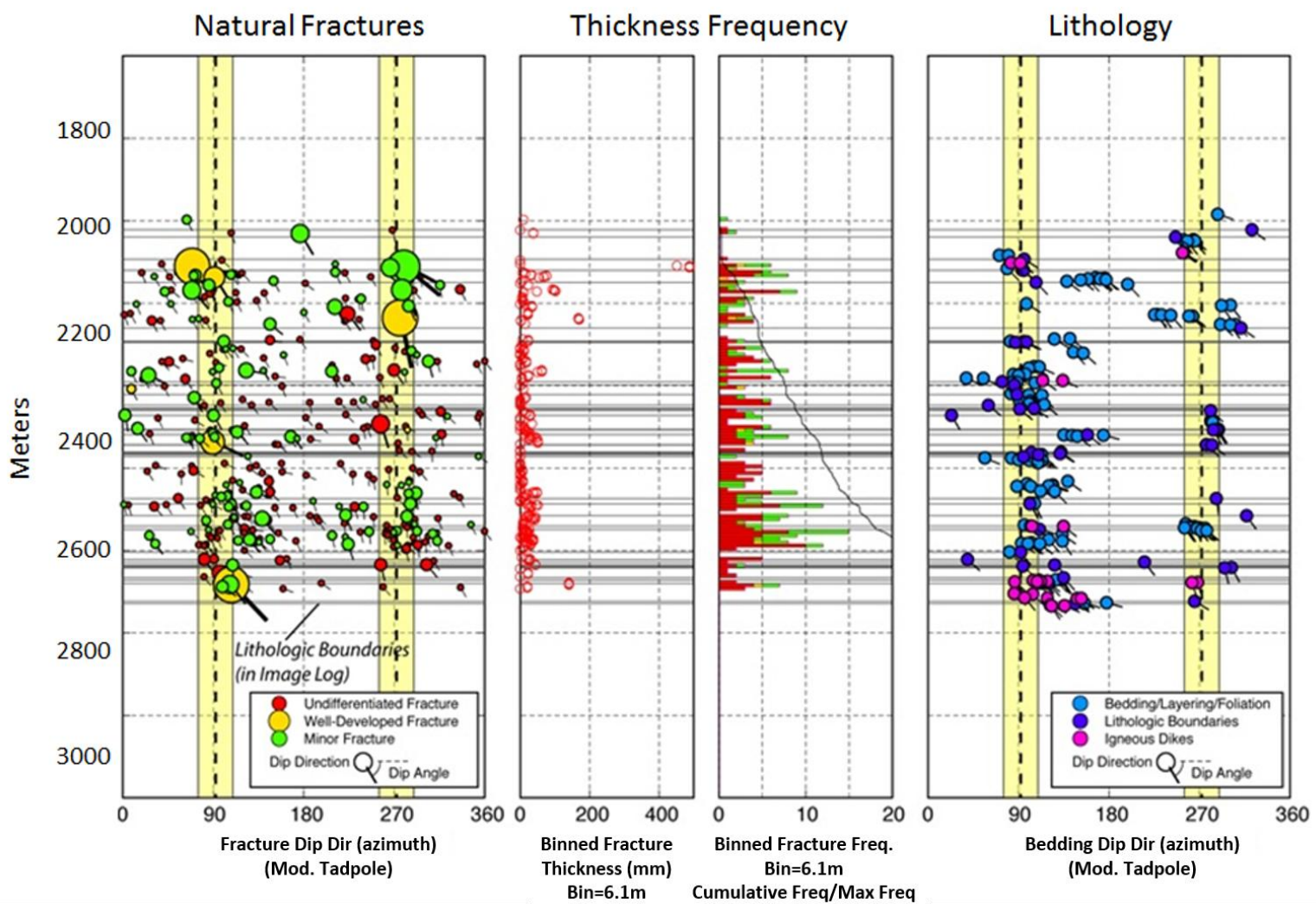

Figure 5. Summary of Borehole Televiewer Data as interpreted in (Davatzes and Hickman, 2011).

Determining the magnitudes of the three principle stresses is more difficult. In a normal faulting regime, the maximum principle stress is vertical (Sv) with a magnitude related to the weight of the lithostatic overburden. The minimum horizontal stress (Shmin) at a given depth is best determined from a mini-frac, a well test in which Shmin is determined from the fluid pressure at which tensile fracturing occurs. An accurate mini-frac requires a short $(15 \mathrm{~m})$ section of relatively unfractured well bore to be isolated. Isolation allows for sufficient pressure build-up to cause tensile fracturing, provides a narrow depth range over which to calculate Shmin, and ensures that the measured pressure response is due to a tensile failure and not hydroshearing. Because NWG 55- 29 has over $1000 \mathrm{~m}$ of open hole and isolating a short section would have required a drilling rig, it was not feasible to conduct a mini-frac to determine Shmin prior to the first stimulation. Shmin and the rest of the stress model was constrained based on reasonable geomechanical assumptions derived from injection tests and material properties (Davatzes and Hickman, 2011; Cladouhos et al., 2011).

Based on this stress model (Table 1) and a stimulation model, we estimated that a well head pressure (WHP) of 90-110 bar (1350-1550 psi) would initiate hydroshearing and that a maximum WHP of 130-150 bar (1950-2150 psi) would be needed to achieved the goals of the project (Cladouhos et al., 2011).

Table 1: Stress model.

\begin{tabular}{|l|l|l|}
\hline Component & Gradient $(\mathbf{M P a} / \mathbf{k m})$ & Direction \\
\hline Sv & 24.1 & vertical \\
\hline SHmax & 23.5 & $2^{\circ}(\mathrm{N}-\mathrm{S})$ \\
\hline Shmin & $14-9-15.8$ & $92^{\circ}(\mathrm{E}-\mathrm{W})$ \\
\hline $\mathrm{Ph}$ & 8.8 & Fluid pressure \\
\hline
\end{tabular}




\section{Cladouhos et al.}

For purposes of modeling and analysis of stimulation potential, the open hole was divided into five zones based on borehole televiewer (BHTV) fracture intensity, lithology, mud losses while drilling, and water losses during the injection tests. The characteristics of these zones are summarized below in Table 2.

Table 2. Summary of geologic zones identified in NWG 55-29.

\begin{tabular}{|l|l|l|l|l|}
\hline Zone & Depth Interval (m) & $\begin{array}{l}\text { Fracture Count } \\
\text { in Zone / (\#/m) }\end{array}$ & Lithology & $\begin{array}{l}\text { Mud Losses during } \\
\text { drilling }\end{array}$ \\
\hline A & $1966-2057$ & $5 / 0.06$ & $\begin{array}{l}\text { Primary: Welded Lithic Tuff } \\
\text { Secondary: Other Tuff }\end{array}$ & None \\
\hline B & $2057-2439$ & $173 / 0.4$ & $\begin{array}{l}\text { Primary: Tuffs } \\
\text { Secondary: Basalt, Dacite, and Andesite }\end{array}$ & $<50 \mathrm{bbl}$ \\
\hline C & $2439-2634$ & $157 / 0.8$ & $\begin{array}{l}\text { Primary: Basalt and Basaltic Andesite } \\
\text { Secondary: Two Felsic Dikes, }\end{array}$ & $<20 \mathrm{bbl}$ \\
\hline D & $2634-2908$ & $16 / 0.06$ & $\begin{array}{l}\text { Primary: Microcrystalline Granodiorite }(5 \text { dikes, } \\
\text { 570 ft total) } \\
\text { Secondary: Basalt, one large (50) felsic dike }\end{array}$ & None \\
\hline$E^{1}$ & $2908-3067$ & $\begin{array}{l}\text { Primary: Basalt } \\
\text { Secondary: Three felsic Dikes }\end{array}$ & $>100 \mathrm{bbl}$ \\
\hline
\end{tabular}

${ }^{1}$ Zone E was not visualized by the BHTV survey. The motor quit working due to the high temperatures at this depth.

\section{PHASE 2, INITIAL SETUP AND 2012 STIMULATION}

Phase 2 of the Newberry EGS Demonstrations began in April 2012 after a Finding of No Significant Impact (FONSI) was issued by the Bureau of Land Management on the project's Environmental Assessment.

\subsection{Micro-Seismic Array (MSA) Installation}

Starting in late May 2012, after snow melt, four new MSA monitoring holes (NN17, NN19, NN21, and NN24 on Figure 6) were drilled to depths between 213 and $246 \mathrm{~m}$. The depth of these holes was chosen so that the geophones could be installed below the water table, in sections of competent rock at least $30 \mathrm{~m}$ long, and below the highly attenuating, unsaturated cinders and debris flows on the flanks of the Newberry Volcano. The holes were drilled using the air hammer and casing-while-drill technique, and were completed with $13 \mathrm{~cm}$ (5 inch) steel casing cemented from TD to the surface. On average the new holes took 11 drilling days to complete. In addition, one existing water well (NN18) was deepened to improve coupling to the bedrock for the geophone. It took 3 months to drill all five holes. In addition, three holes drilled in 2009 and 2010 for temperature gradients (NN32, NN09, and NN07 on Figure 6) were used as monitoring holes.

Seismic equipment installation began in early August 2012. Two-Hz 3-component geophones were installed at seven surface sites and eight borehole sites. The surface equipment at each site included two 80-Watt solar panels, a GPS antenna and one or two cell phone antennas mounted in a tree to ensure that snow would not cover equipment that needed to stay exposed. In a Hoffman box at the base of the tree, a digitizer, wireless cell modem, solar charge controllers, and two 12-V batteries were installed.

At each of the borehole stations an orientable hole-lock was installed near TD. A hole-lock is a device that is installed in the wellbore before installation of the geophone and oriented using a downhole gyroscope. The hole-lock has a wedge like locking device which forces the geophone to be oriented a certain way when it slides into a resting position. Knowledge of the orientation of the horizontal components was required in order to maximize location accuracies and determine source mechanisms for the earthquakes. The 15 stations stream continuous data via cell phone modem to a server running acquisition software at AltaRock's office in Seattle where the continuous data are saved and archived. Triggered waveforms were sent to Lawrence Berkeley National Lab (LBNL) for locating and publishing to their public website (LBNL, 2015). Microseismic events were also analyzed by the Pacific Northwest Seismic Network (PNSN, 2015) and Foulger Consulting, who focused on deriving moment tensor solutions, calculating relative locations, and improving the crustal model (e.g. Julian and Foulger, 2004).

The regional seismic network at Newberry Volcano has improved greatly in the past four years. In 2009, the only station was NCO, a single-component, short-period seismometer on the east flank and only four microearthquakes (M 1.3-2.2) were detected in Newberry in the prior 25 years (PNSN, 2015). In 2011, the USGS installed six three-component broadband seismometers and one three-component short-period sensor (PNSN, 2015). Four of the borehole stations in the AltaRock Newberry MSA (NN32, NN19, NN17, and NN21) were also added to the PNSN network. The seismic coverage of Newberry Volcano is now comprehensive, with events smaller than M 0.0 being locatable. During the 2012 stimulation, about 175 events were located in the stimulation zone with magnitudes between $\mathrm{M} 0.0$ and M 2.3 (Cladouhos et al., 2013). Between March 1, 2013 and Sept. 20, 2014, a time during which there were no stimulation activities in the area, there were about 60 natural seismic events located in the Newberry edifice (PNSN, 2015). This elevated background seismicity does not indicate increased seismicity due to natural causes or EGS activities. Instead, it is a consequence of the much improved seismic network being able to locate much smaller events over a large area. During the 2014 stimulation, about 398 events were located in the stimulation zone with magnitudes between M 0.0 and M 2.2 (Cladouhos et al., 2015). 
Cladouhos et al.

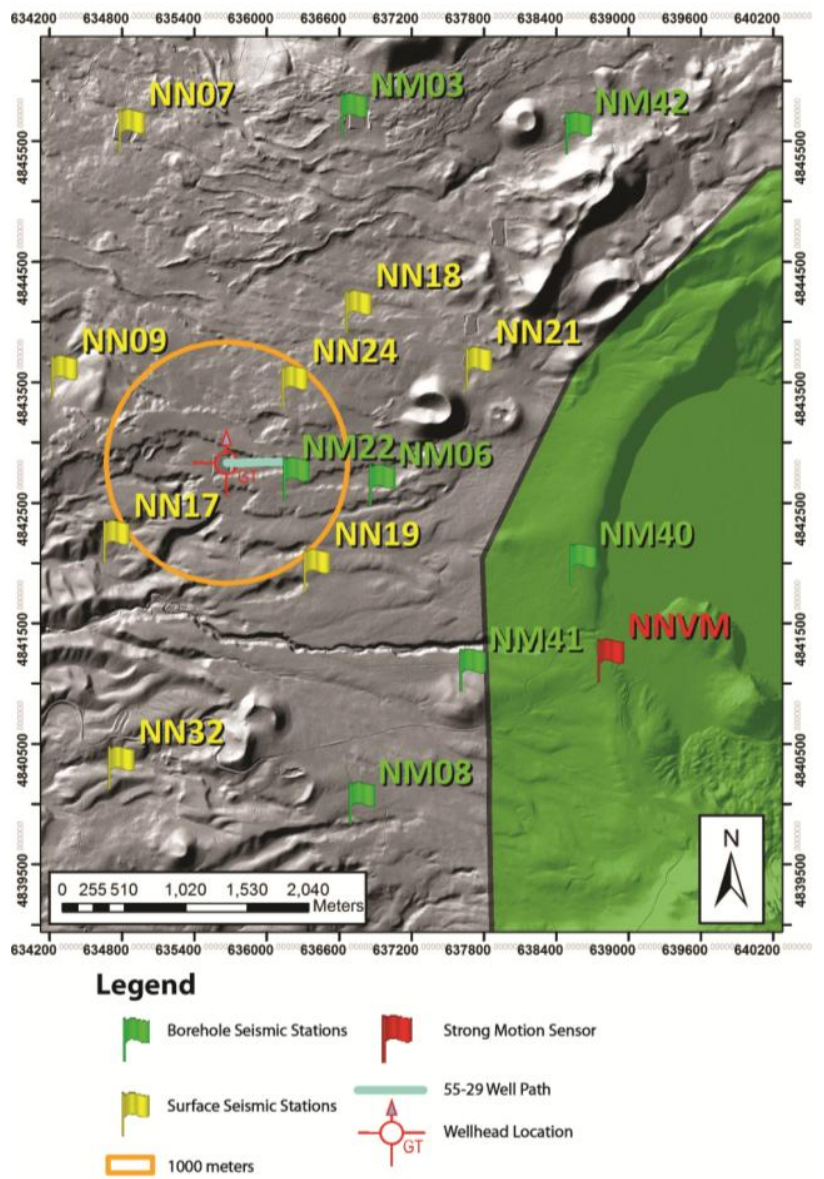

Figure 6: MSA locations, EGS well 55-29, and Newberry National Volcanic Monument (green shading).

\subsection{Stimulation Results}

During the first stimulation, the well head pressure (WHP) reached 167 bar (2450 psi), 40,000 $\mathrm{m}^{3}$ (11 million gallons) of water were injected, and over 175 microearthquakes were located, illuminating an EGS reservoir with a bimodal distribution of depths (Figure 7). While the horizontal extent of the microseismic cloud was impressive, about $90 \%$ of the events were above the casing shoe, suggesting that injected fluid had leaked out of the casing to stimulate relatively shallow and cool rock. After confirming that the bimodal distribution of seismic events was not due to seismic depth errors it was hypothesized that it was due to either holes in the casing stimulating a shallow zones in the wellbore or high permeability pathways connecting the two depths.

Well surveys in 2013 determined that there were two shallow leaks in the 13 3/8" casing and that well repairs and a second stimulation would be necessary to create a deeper, hotter EGS reservoir. Additionally, the well surveys confirmed that a blockage had formed during the 2012 stimulation at $2100 \mathrm{~m}(6888 \mathrm{ft})$, so that a slotted liner would be required to keep this section of the hole open and available for logging.

The biggest event during the 2012 stimulation was $\mathrm{M}_{\mathrm{w}} 2.39$ which occurred on the last day of stimulation (Dec. 7, 2012) exceeded the initial ISMP limit of $\mathrm{M}_{\mathrm{w}}$ 2.0, on magnitude. The mitigation action for this limit was to wait 24 hours before increasing well head pressure or flow rate. Since the event occurred on the last day of planned stimulation, no modification to operational plans was necessary, and the well was shut-in later that day.

Ground motion at the NNVM SMS due to the $\mathrm{M}_{\mathrm{w}} 2.39$ event had an estimated peak ground acceleration (PGA) of $0.1 \% \mathrm{~g}$, far below the action threshold set in the ISMP (AltaRock, 2011) of 1.4\% g. From the seismometer closest to the event, a borehole seismometer at NN17, a PGA of $0.3 \% \mathrm{~g}$ was estimated. That level of ground motion would not necessarily have occurred at the surface, due to the highly attenuating cinders blanketing the volcano flanks. In any case, there were no reports of any felt seismicity from the field crews on-site for this or any other microearthquake. Due to winter conditions, no visitors were near the site. 


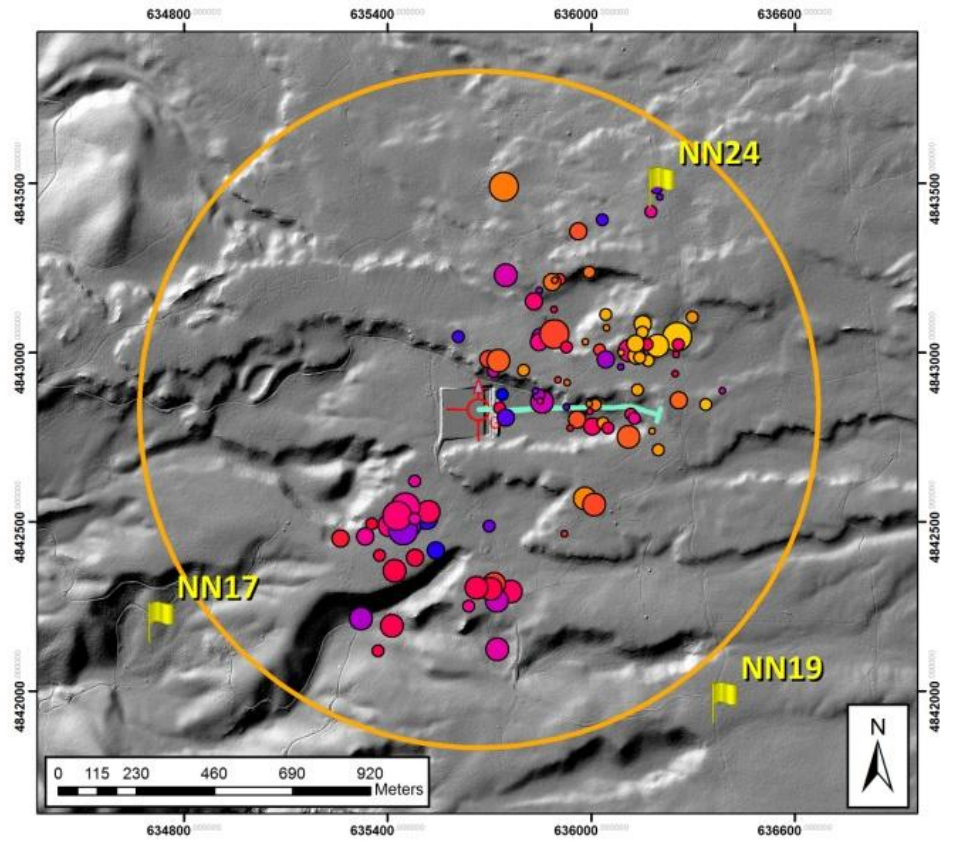
Magnitude (Mw) Depth BGS (m)
- $0.0-0.5 \bullet 0-500$
- $0.5-1.0 \bigcirc 500-1000$
○ $1.0-1.5$ ○ $1000-1500$
○ $1.5-2.0$ ○ $1500-2000$
$2.0-2.5 \bigcirc 2500-3000$
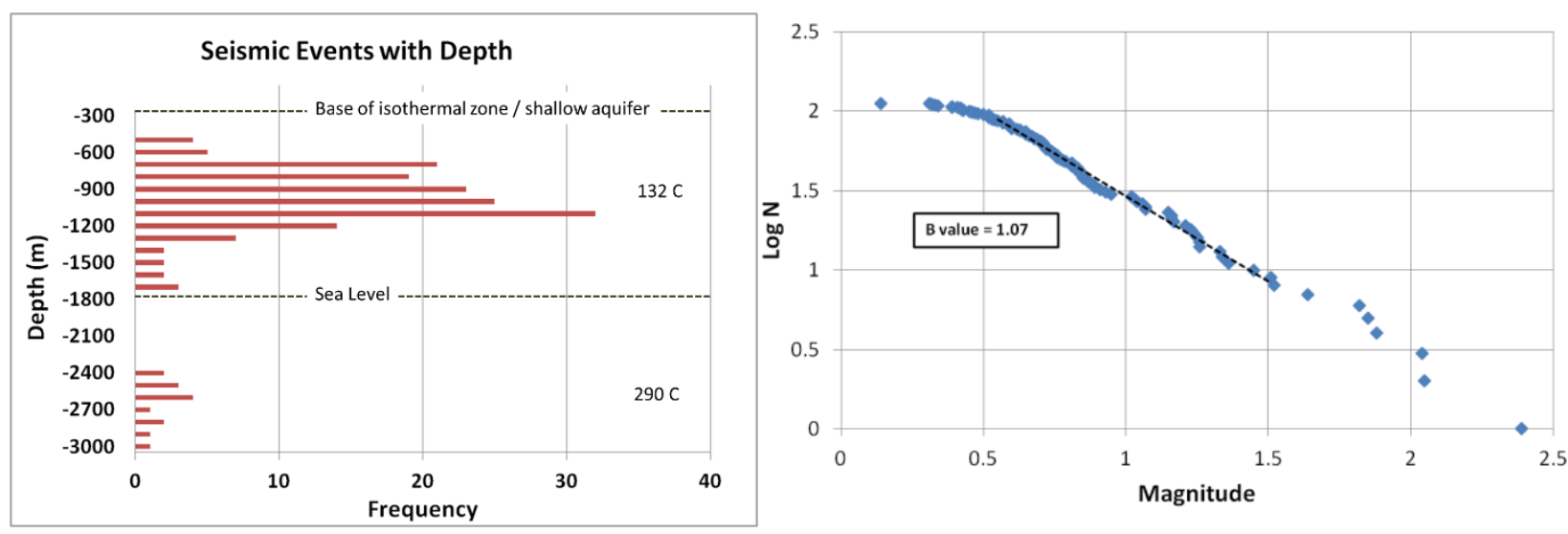

Figure 7: Summary graphics of microseismicity during 2012 EGS stimulation.

\section{SECOND STIMULATION: 2014}

\subsection{Rig Work}

The Paul Graham Drilling Rig 9 was mobilized to the site and rigging up completed on August 9, 2014. After running a bit to bottom to clear obstructions, a bridge plug was set and $95 / 8$ " casing was tied-back from $1250 \mathrm{~m}$ (4100 ft) to the surface, inside $133 / 8$ " casing. The casing was then cemented in place. Next a 7" slotted liner was installed in the open-hole from the $95 / 8$ " shoe to bottom (Figure 4). The rig was released August 23.

\subsection{Pump Re-installation}

After the drill rig was demobilized, the stimulation pumps, originally procured from Baker Hughes CentraLift in 2012 were re-installed on the pad (Figure 8). The two horizontal centrifugal pumps were designed with high-pressure piping and valve arrangement that allows them to operate in series or parallel The maximum injection pressure that can be achieved by the equipment is approximately 195 bar (2850 psi) with a flow rate up to $50 \mathrm{~L} / \mathrm{s}(800 \mathrm{gpm})$. Lower flow rates can be achieved through a bypass system. The electric pumps, powered by diesel generators, are ideal for long duration stimulations and require less maintenance compared to positive displacement pumps. 
Cladouhos et al.

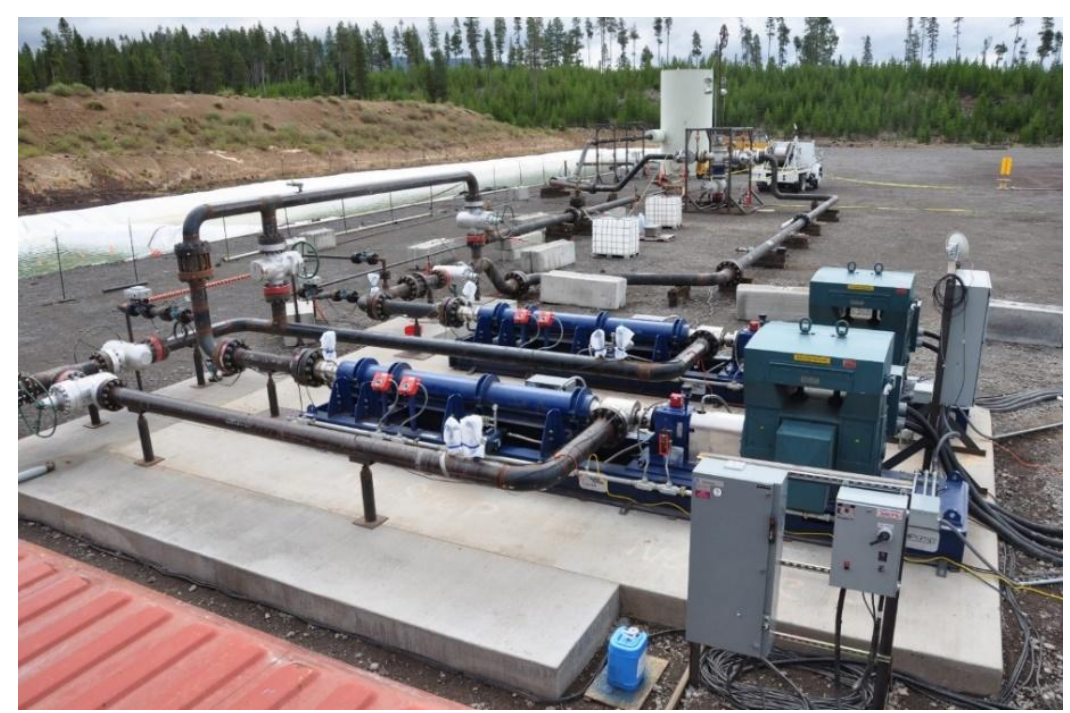

Figure 8: Horizontal, centrifugal pumps (blue), electric drives (green), and 10 inch (OD) piping to well head in the background.

\subsection{STIMULATION}

\subsubsection{Overview}

Injection into NWG 55-29 began on Sept. 22, 2014 to cool the wellbore in preparation for installation of a fiber optic distributed temperature sensing (DTS) cable. On September 23, rig up and testing of the stimulation system was completed and an initial step-rate test (srt) was conducted from September 23-26 (see Figure 9 for WHP and flow summary). The first round of stimulation continued until October 13, with WHP generally over 180 bar (2600 psi) except for brief episodes related to leak fixing, pump trips, or well logging. Two TZIM treatments were injected on October 13-14 before shutting the pumps off and shutting the well-in on October 15 . After the first 3-week round of stimulation, the well was allowed to heat up for 7.5 days and a flow test was conducted on October 23 . During a hibernation period from October 23 to November 10, the first round stimulation data was assessed and used to finalize round 2 stimulation plans.

On November 11, the stimulation pumps were restarted and a low pressure step-rate injectivity test was completed to determine the permanent change in injectivity caused by the stimulation. This test was followed by a period of constant pumping pressure at 151 bar ( $2200 \mathrm{psi}$ ), to cool the wellbore in preparation for perforation shots. On November 13, Cogco Wireline performed two perforation shots

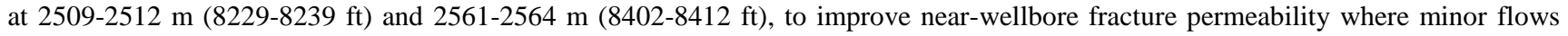
were already occurring. Following the perforation shots, the well was allowed to flow back briefly to clean out any debris from the shots, before restarting stimulation on November 14. A return to high pressure stimulation began on November 14 and lasted for one week. TZIM was injected on November 18 and 19 to block the initial flow zones and allow stimulation to open new zones. Injection ended on November 20. Upon conclusion of the second round stimulation, the well was shut in and allowed to heat up for 3.5 days while the pad was cleared of stimulation equipment. From November 24-26, a second flow test was conducted.

\subsubsection{Well Head Pressure, Flow and Injectivity}

A low pressure step-rate test from 83-138 bar (1200-2000 psi) WHP was conducted overnight on September 23-24 (Figure 9). At these pressures, flow rates were below $1.9 \mathrm{l} / \mathrm{s}(30 \mathrm{gpm})$ and a very low injectivity index of $0.009(1 / \mathrm{s}) / \mathrm{bar}(0.01 \mathrm{gpm} / \mathrm{psi}) \mathrm{was}$ determined (Figure 10). After piping leaks were repaired on September 24, the step rate test continued to 179 bar (2600 psi) WHP. The flow rates at this pressure exceeded $3.8 \mathrm{l} / \mathrm{s}(60 \mathrm{gpm})$ with a noticeable increase in injectivity to $0.027(1 / \mathrm{s}) / \mathrm{bar}$ during the steps from $165-179$ bar (2400-2600 psi) (Figure 10). Injectivity continued to increase to about 0.04 (1/s)/bar by October 1 . This injectivity improvement was permanent as indicated by low pressure step-rate testing on November 11 and high pressure step-rate testing on October 15.

Flow rate spikes (e.g. on September 27 on Figure 9) occurred when step rate pressure changes caused temporary high flows followed by a decline in flow rate over an hour to lower flows. Thermohydrologic (TH) modeling using TOUGH2 (Sonnenthal et al., 2015 and Section 6 below) indicates that this behavior can be explained by compression of the water due to the pressure increase in the well bore and formation.

Numerical modelling presented in Cladouhos et al. (2011) predicted that microseismicity and injectivity improvement would initiate at a WHP of 93 bar (1350 psi) and that 134-151 bar (1950-2200 psi) would be sufficient to reach the required reservoir volume goal. The 2012 stimulation (Cladouhos et al., 2013a, 2013b) seemed to confirm this prediction with injectivity improvements and deep seismicity $(>2.4 \mathrm{~km},>8000 \mathrm{ft}$ ) initiating at a WHP of 94 bar (1360 psi) and four additional deep seismic events occurring at a WHP of $132 \mathrm{bar}$ (1910 psi). Thus the need to exceed 165 bar (2400 psi) WHP to promote stimulation was unexpected. The practical effect is that the stimulation pumps reached their maximum pressure of 196 bar (2850 psi) on Sept. 29, the sixth day of the stimulation. Stimulation was continued because microseismicity indicated that the EGS reservoir did continue to grow despite stable injectivity at the well bore. Surface equipment, shoe depth and regulatory agreements also specified that the stimulation pressures be kept below 210 bar (3000 psi), so the pump performance was not the only limit preventing significantly higher pressures. 

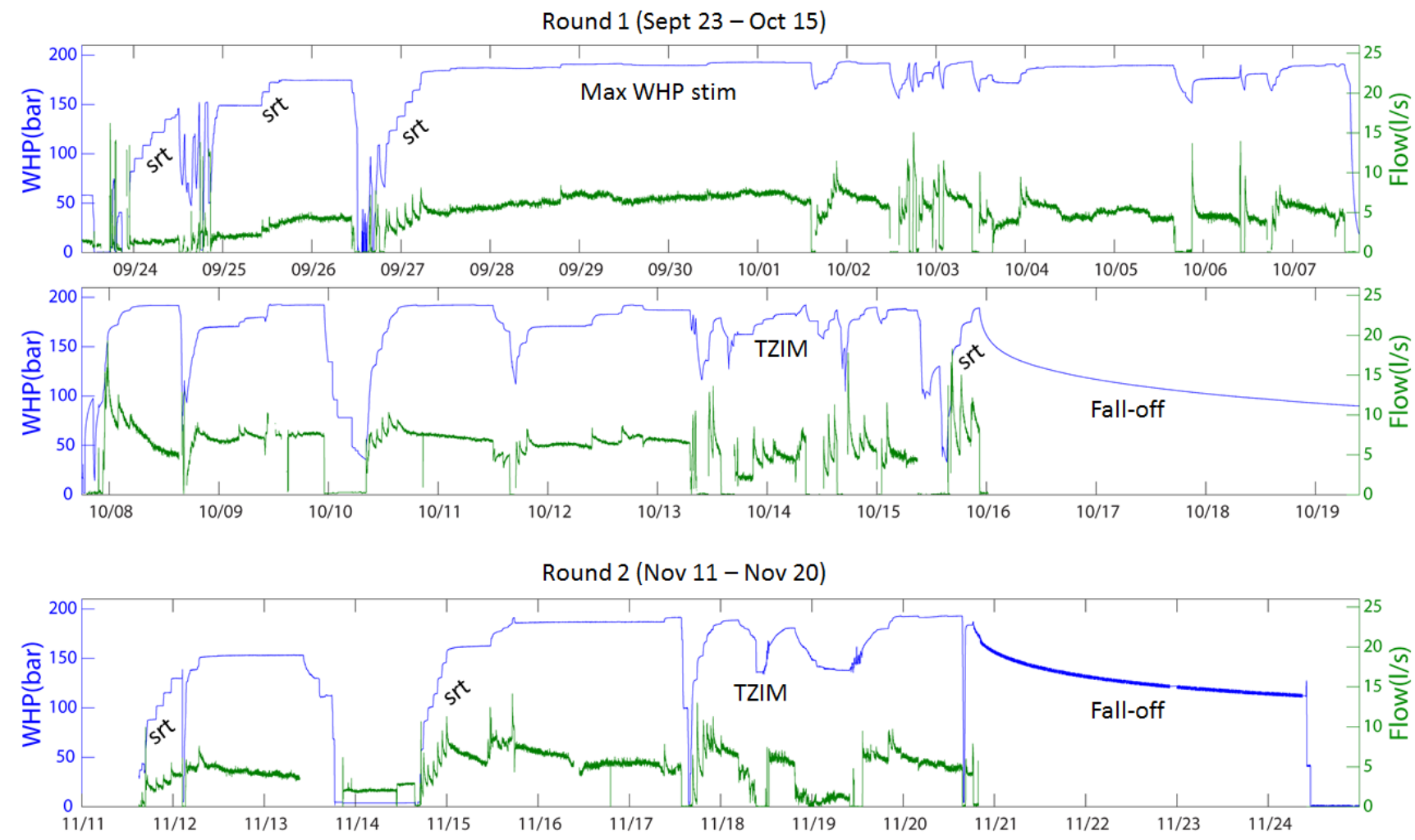

Figure 9: Well head pressure (blue) and flow rate (green) records during round 1 (top two panels) and round 2 (bottom panel) of 2014 stimulation. Times of step-rate test (srt) and TZIM treatments are shown.

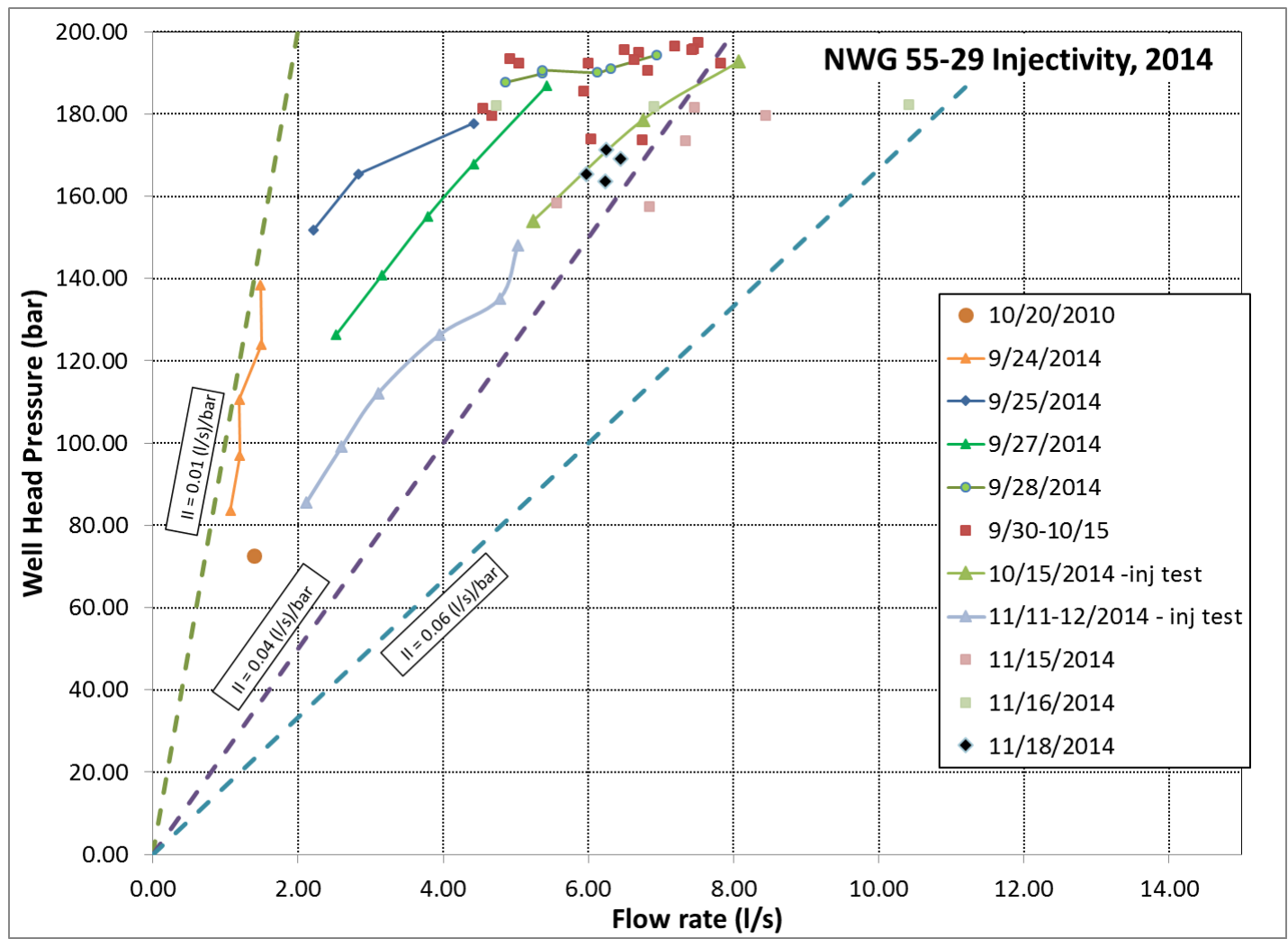

Figure 10: Injectivity index ((l/s)/bar) on various dates. Points linked by lines are from step rate tests (srt) labeled in Figure 9. 


\subsubsection{Temperature data}

A fiber optic distributed temperature sensing cable (DTS) was installed to the well on September 22. While running the DTS cable into the well, the cable was weight tested every $305 \mathrm{~m}(1000 \mathrm{ft})$ and signal tested periodically to ensure good signal return to surface. When the cable reached $2913 \mathrm{~m}(9556 \mathrm{ft})$, a signal test with a power meter showed no signal returns. After connecting the fiber to the signal box, it was determined that a fiber break occurred at approximately 2378-2393 m (7800-7850 ft) in both channels. The cable was lowered as much as possible and the DTS box configured for single channel mode and monitor depth to approximately $2439 \mathrm{~m}(8000 \mathrm{ft}$ ) downhole. This length of cable allowed operators to monitor well bore cooling and confirm the integrity of the casing and casing shoe, however it did not capture any information about fluid exit zones within the well, all of which were located below the monitored depth. Therefore, the DTS cable was pulled out on Oct. 15 at the conclusion of round one of stimulation.

After retrieving the DTS cable, a memory pressure, temperature, and spinner (PTS) tool was used to log to $2987 \mathrm{~m}$ (9800 $\mathrm{ft}$ ) while the well was put on flow back. After the first survey run, the well was then put on injection and the PTS tool was again lowered to $2987 \mathrm{~m}$ (9800 ft) in order to observe permeable zones. At the end of the injection survey, the PTS tool was pulled up to $1220 \mathrm{~m}$ (4000 $\mathrm{ft}$ ) and used to monitor downhole pressure while a step-rate injectivity test was performed. At the end of the injectivity test, the well was shut-

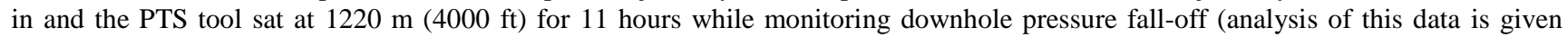
below). Four PTS log runs were also collected as part of the TZIM treatment from November 17-20. These logs are discussed below as well.

\subsubsection{Microseismicity}

As is typical of hydraulic well stimulation, the rate of seismicity correlates to well head pressure and flow rate (Figure 11). Microseismicity did not commence until a WHP of 179 bar (2600 psi) was exceeded. Over 30 events per day were located on Oct 1-3 after the WHP exceeded 193 bar (2800 psi). After five days of increasing seismicity and improving injectivity, the seismicity rate dropped by more than $50 \%$ by October 6 . Additional modeling (i.e. Sonnenthal et al, 2015) and further analysis have been undertaken to better understand the drop in seismicity rate and early peaking of the injectivity improvement.

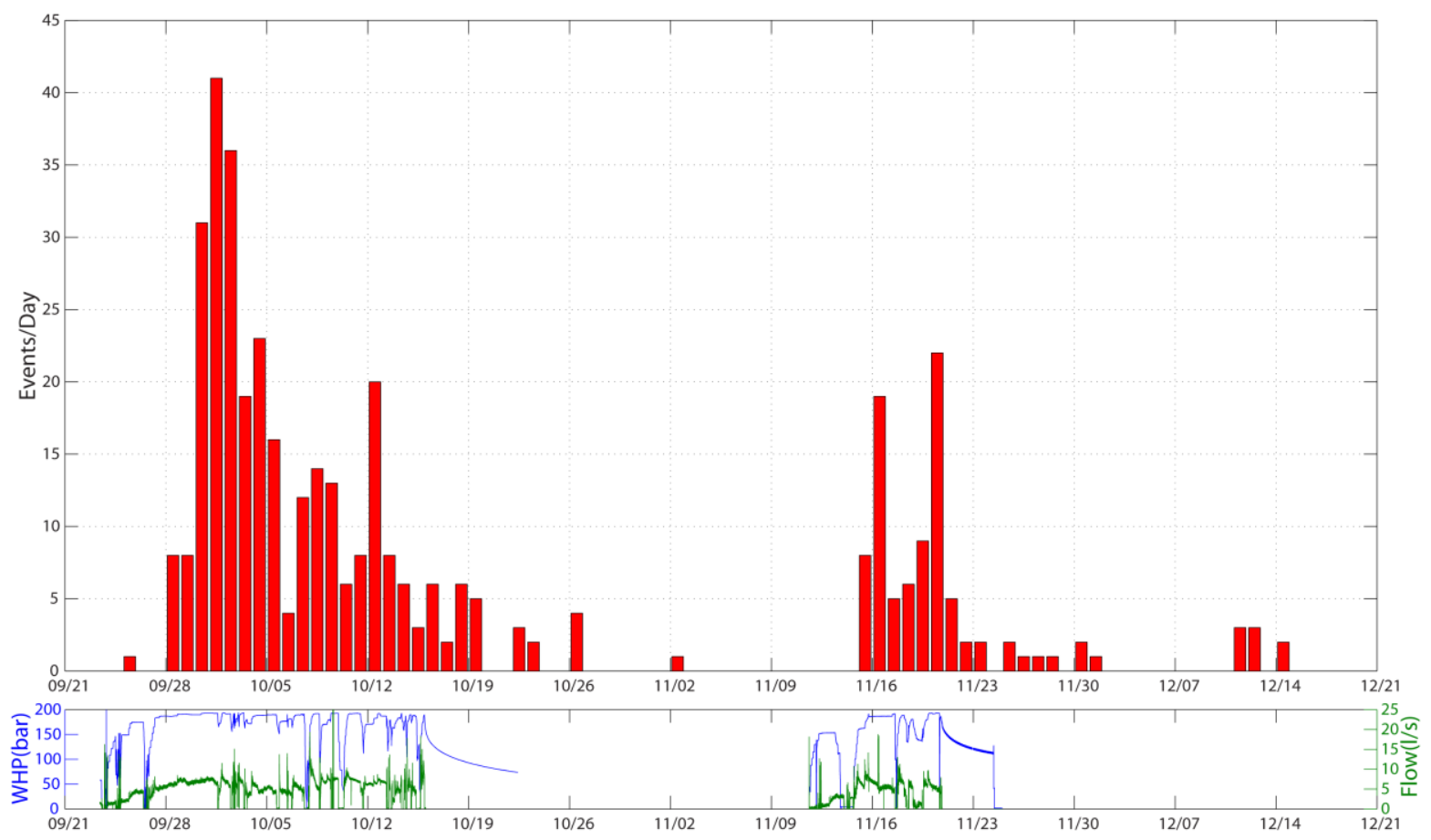

Figure 11: Temporal histogram of microseismic events $(\mathrm{N}=398)$.

Triggered waveforms were analyzed by multiple means. First, the seismic acquisition software automatically identified events, generating preliminary P- and S-wave picks and locations. The software sent an alert email to project scientists and seismologists including a map of the preliminary location. In addition, waveforms were sent to LBNL and Foulger Consulting. The P\&S-wave arrival time measurements for all triggered events were reviewed by a seismologist within a day, resulting in a location catalog of 398 handpicked events. The original locations of the 398 microseismic events were diffuse and plotted up to $500 \mathrm{~m}$ ( $1640 \mathrm{ft})$ from the injection well. Relative relocations performed after the stimulation was complete show a tighter microseismic cloud (Figure 12). 

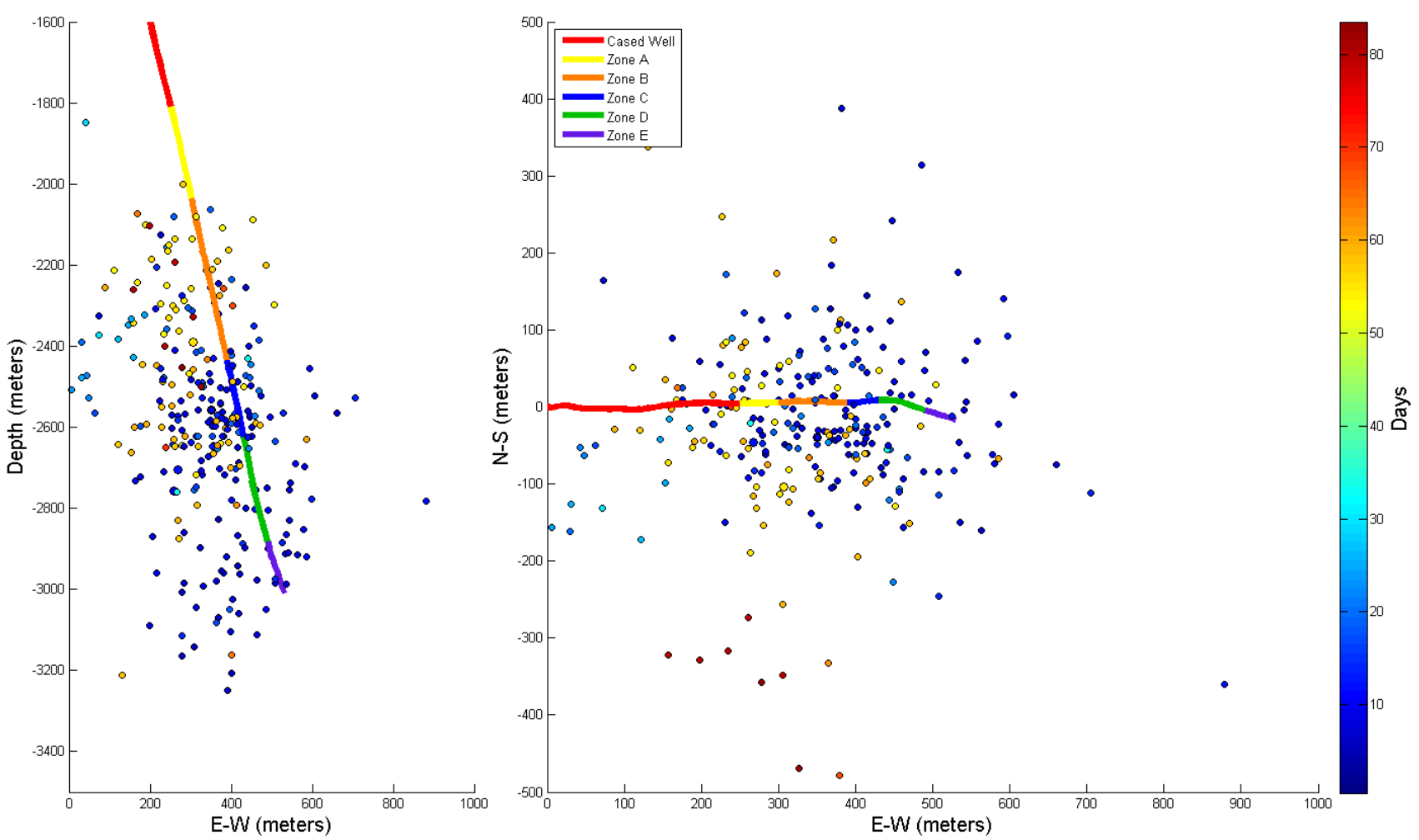

Figure 12: Relocated microseismic events in relation to well bore. . (Left) North-looking cross section of bottom part of 55-29. (Right) Map view. Microseismic events are color-coded to the days from the start of the stimulation. The well is colorcoded to the geologic zones defined in Figure 4.

To determine more accurate individual locations, and calculate moment tensors, Foulger Consulting re-measured arrival times for the 100 largest individual earthquakes as follows.

1. The triggered waveforms were imported into the Foulger Consulting interactive seismogram processing program epick;

2. In a first sweep through the data, $\mathrm{P}$ - and $\mathrm{S}$-wave arrival times were measured and an initial location calculated;

3. In a second sweep through the data, each channel was re-processed, rotating the seismograms from a geographic reference frame (up-down, east-west and north-south) to a ray-path reference frame (up-down, radial, and transverse);

4. The seismograms were filtered with a 5-Hz high-frequency cut-off, $\mathrm{P}$ - and $\mathrm{S}$-wave polarities and amplitudes were measured, and additional S-wave measurements were added where enhancement by the rotation process made this possible;

5. The earthquake was relocated, the residuals examined, and arrival-time measurements with large residuals were checked and corrected where appropriate.

This process resulted in a catalog of exceptionally high quality locations and moment tensors for 100 events. The locations of the 100 best-located events (Figure 13, right), mostly lie within $200 \mathrm{~m}(656 \mathrm{ft})$ of the well bore, are significantly less diffuse than the full catalog or the relocated events. 

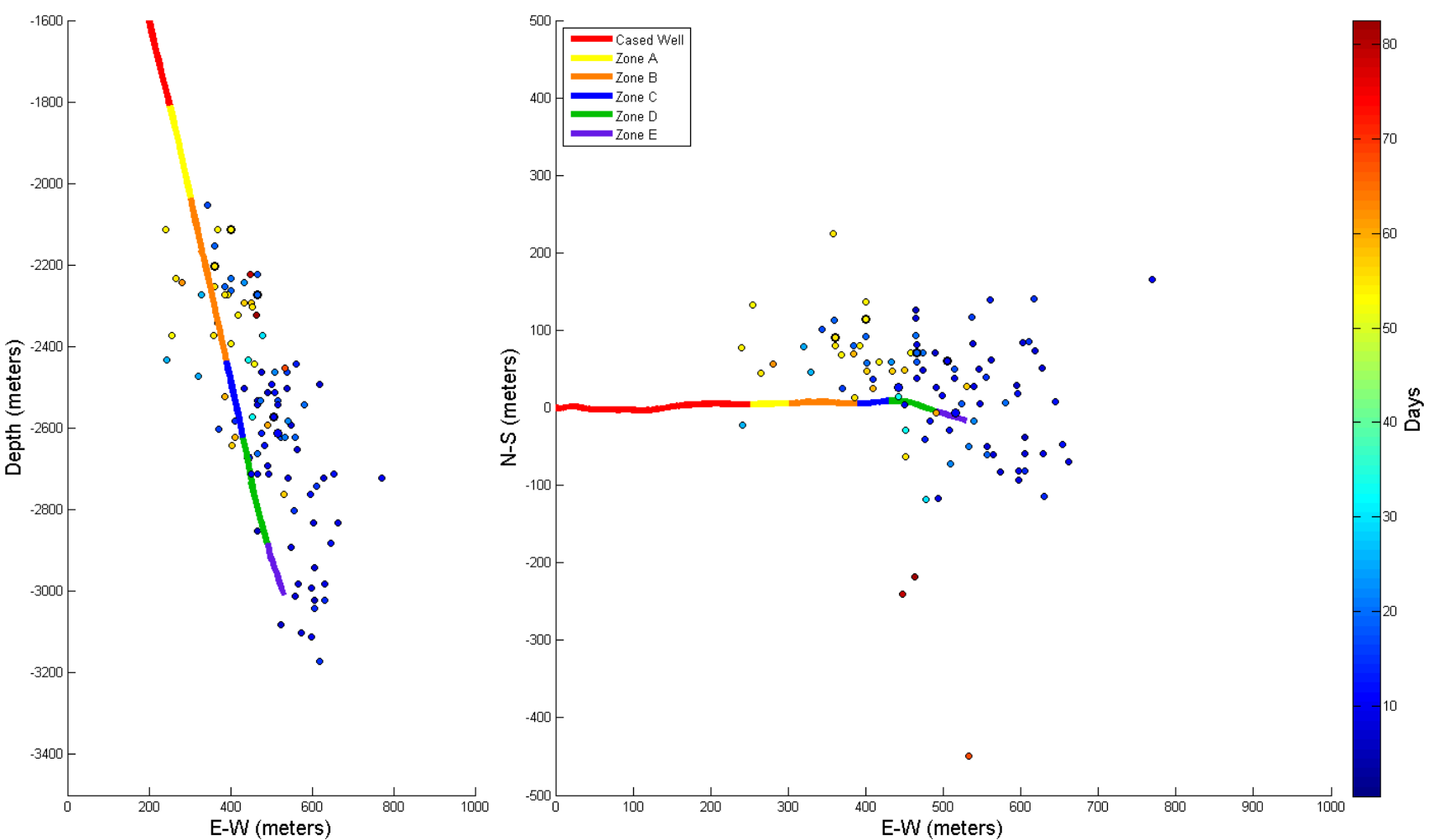

Figure 13: Microseismic events analyzed for moment tensors in relation to well bore. (Left) North-looking cross section of bottom part of 55-29. (Right) map view.

To hydraulically characterize the seismically active stimulated region around the well, pore-pressure diffusion theory was applied to the temporal distribution of events around the well. This is done by measuring the distance of each event from the well (r) and plotting against the time of the event $(\mathrm{t})$ (Figure 14). The spatial distribution of the events over time has a triggering front with a parabolic signature (Parotidis, et al., 2004):

$$
r=\sqrt{4 \pi D t}
$$

where $r$ is the distance of the triggering front, $t$ is time, and $D$ is the hydraulic diffusivity of the surrounding rock. After pumping of the well has ceased, and the well is shut-in, seismicity continues to spread away from the well but develops a parabolic back-front:

$$
r=\sqrt{6 D t\left(\frac{t}{t_{0}}-1\right) \ln \left(\frac{t}{t-t_{0}}\right)}
$$

where $t_{0}$ is the shut-in time. The event distances with time were fit to parabolic triggering (Equation 1) and back fronts (Equation 2) using a hydraulic diffusivity value of $0.006 \mathrm{~m}^{2} / \mathrm{s}$ and is shown with the wellhead pressure and flow curves in (Figure 14). This value of hydraulic diffusivity is in the range of observed diffusivity values for fractured and unfractured igneous rocks (Roeloffs, 1996). 
Cladouhos et al.
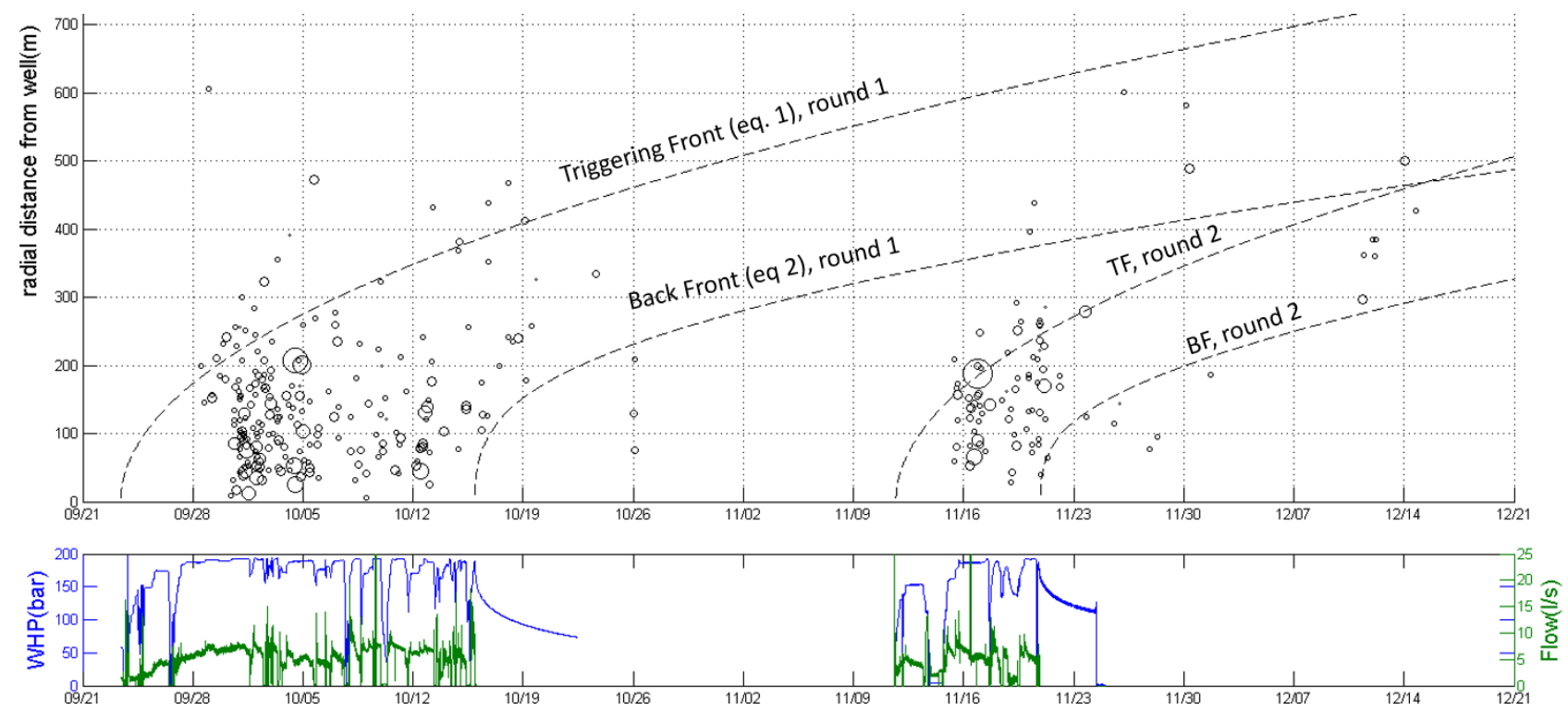

Figure 14: Plot of radial distance of microseismic event from the well vs event time. Size of circles indicate event magnitudes. Hydraulic diffusivity (D) of curves (equations $1 \& 2$ ) shown is $0.006 \mathrm{~m}^{2} / \mathrm{sec}$.

The most reliable moment magnitudes for the induced microseismic events were determined by LBNL. The 350 LBNL magnitudes were used to determine the Gutenberg-Richter Law b-value of 1.0 (Figure 15). The only two events above M 2.0 during the 2014 stimulation were an M 2.1 on October 4 and M 2.3 on November 17. There were 23 events between M 1.0 and 2.0. The rollover of the size distribution below M 0.0 (Figure 15) indicates that the seismic system's lower sensitivity threshold was near M 0.0 .

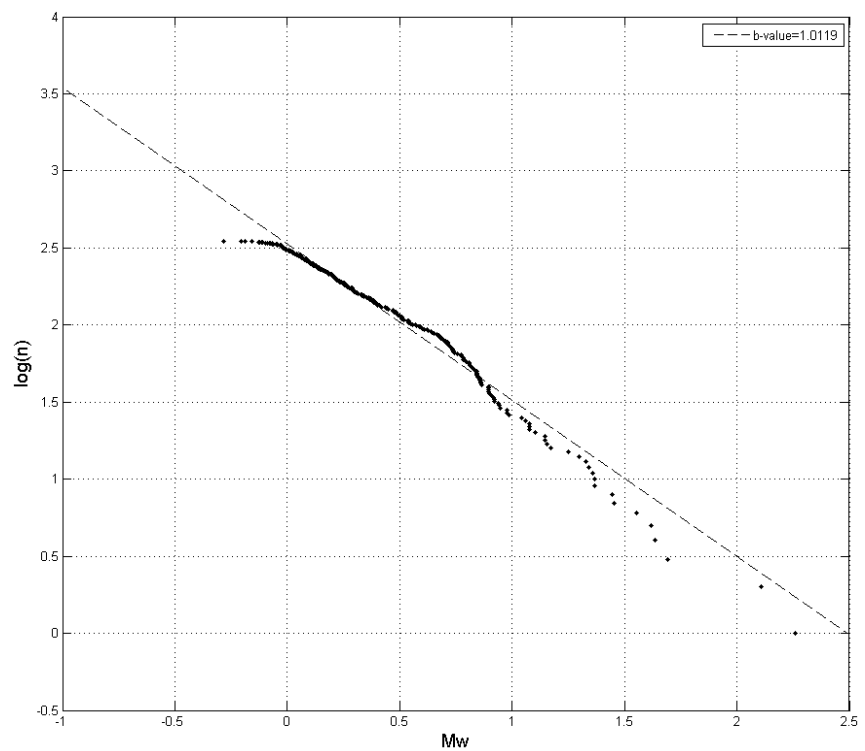

Figure 15: Log-log plot of size distribution of MEQs. Slope of line is b-value in the Gutenberg-Richter Law 


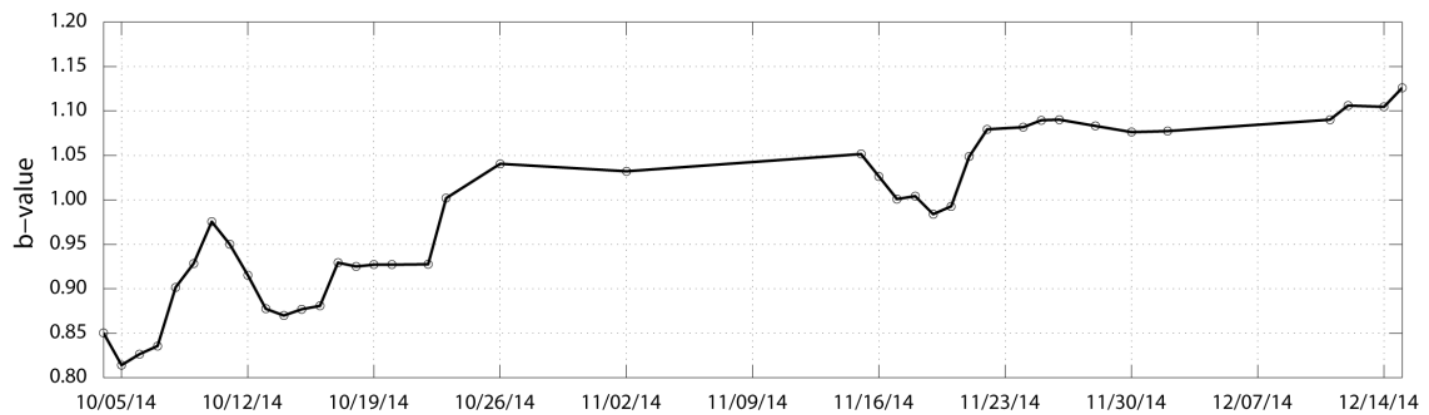

Figure 16: Evolution of b-value during stimulations. Calculated from last 100 events.

In addition, we tracked the evolution of the b-value during the stimulation as part of the ISMP. At the end of each day the size distribution of the previous 100 events was plotted and the b-value calculated (Figure 16). This figure shows that although the overall $b$ value was 1.0, the sliding window of 100 events started low (0.85) and trended upward (1.1). Dips in the trend were associated with events with $\mathrm{M}>1.3$ on October 5, October 12, October 13, November 16, and November 17.

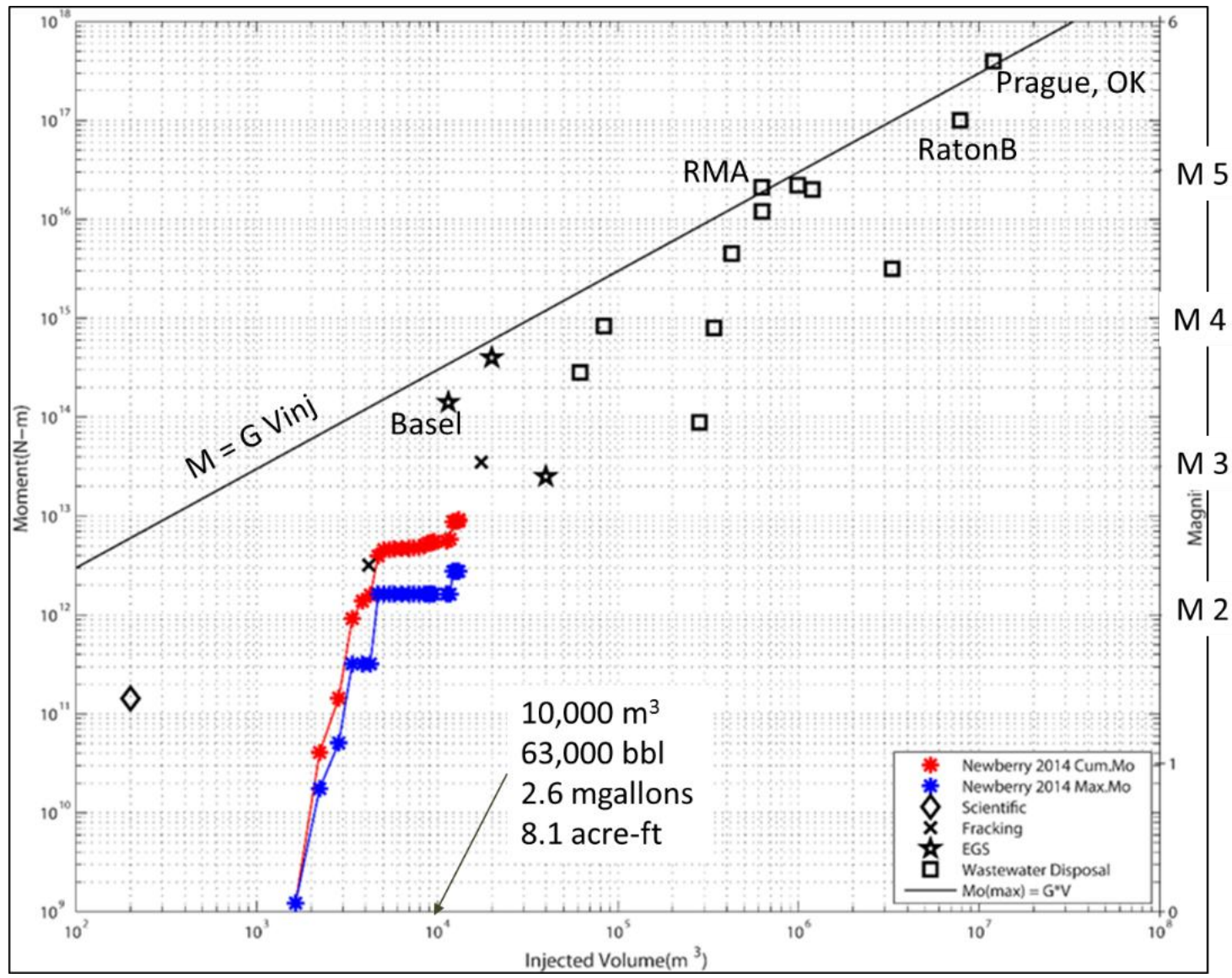

Figure 17: Maximum seismic moment and magnitude as functions of total volume of injected fluid from the start of injection until the time of the largest induced earthquake compiled by McGarr (2014). For Newberry data points, the values were plotted daily, and cumulative moment magnitude included as well as the maximum moment.

McGarr (2014) proposed a simple relationship between the maximum moment of induced seismicity and volume change due to extraction or injection of fluid:

$$
\mathrm{M}_{\mathrm{o}(\max )}=\mathrm{GV}_{\mathrm{inj}}
$$

where $\mathrm{M}_{\mathrm{o}(\max )}$ is the moment of the largest possible induced event, $\mathrm{G}$ is the modulus of rigidity of the rock mass and $\mathrm{V}_{\text {inj }}$ is the injected volume of fluid in cubic meters (we only need consider injection here). McGarr (2014) compiled data from injection projects worldwide to compare to the theoretical limit on induced seismicity magnitudes. In order to track seismic risk at Newberry, we plotted cumulative injected volume, cumulative moment magnitude, and maximum moment magnitude and overlaid them on the McGarr (2014) data compilation (Figure 17). The ratio of seismic energy to volume of injected water at Newberry was significantly lower than at other sites 


\section{Cladouhos et al.}

that have experienced seismicity due to fluid injection. Thus, the Newberry site appears to have a much lower seismogenic index (Shapiro et al., 2010) than other sites. The Newberry data points fall far below the line plotted from the empirical formula developed by McGarr (2014) on a plot of maximum seismic moment to injected volume.

\subsubsection{Thermally-degradable zonal isolation materials (TZIM)}

During both rounds of the 2014 stimulation, AltaVert 251 , designed to degrade above $200^{\circ} \mathrm{C}\left(400^{\circ} \mathrm{F}\right)$ in less than a week, was used in two forms: powdered and fibrous. During round 2 injection of TZIM, a conservative tracer was injected prior to each TZIM stage. In order to monitor diversion in real time during round 2 TZIM injection, a surface readout PTS provided by Well Analysis Corp was used. Four PTS surveys were completed from Nov 17-20 (Figure 18).
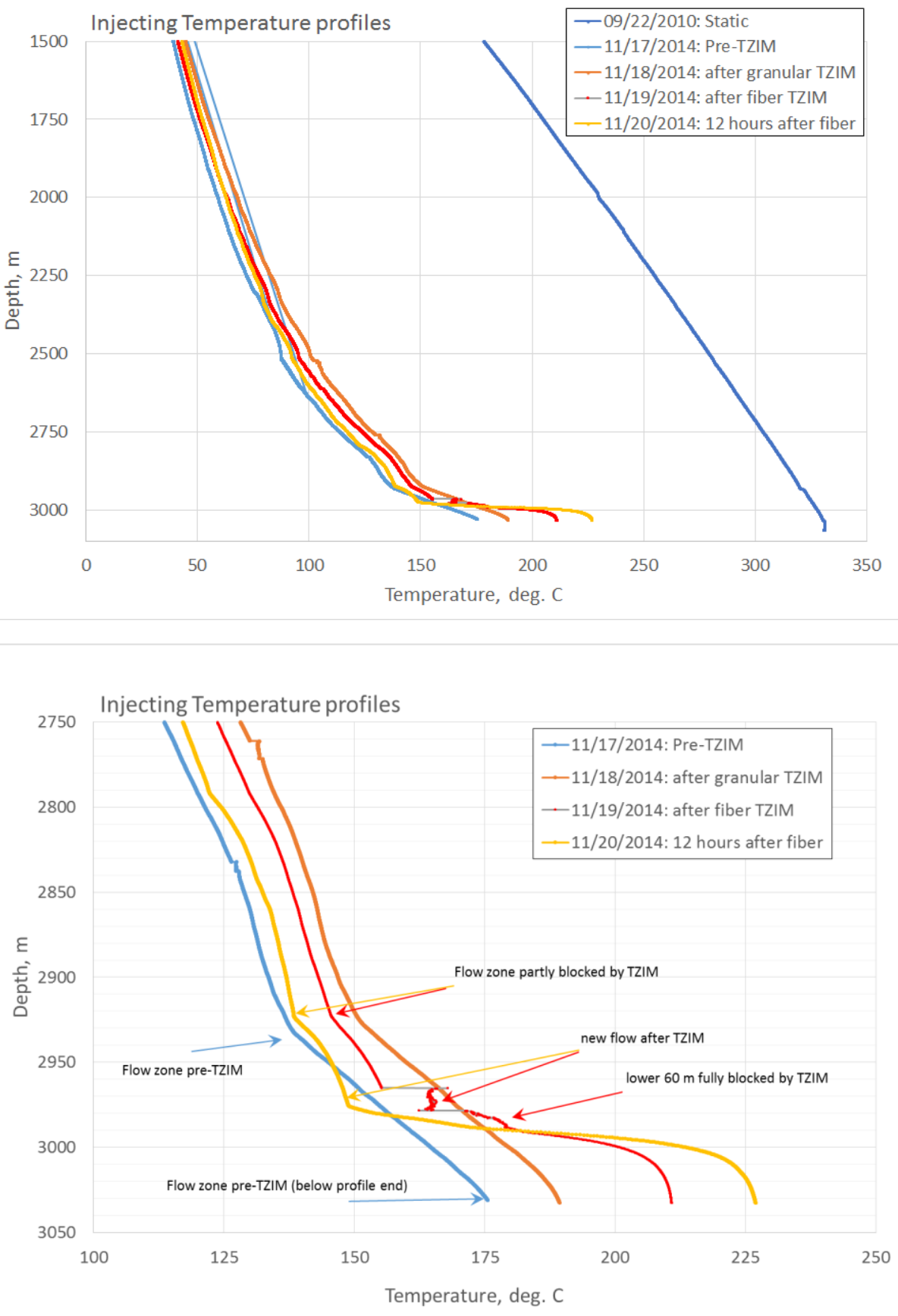

Figure 18: Temperature profiles from PTS logging. (top) $1524 \mathrm{~m}(5000 \mathrm{ft})$ to TD to show all open hole and static profile (bottom) Detail in bottom $305 \mathrm{~m}(1000 \mathrm{ft})$ of open hole to show blocking and opening of flow zones caused by TZIM 
The first injecting temperature survey was taken on November 17, prior to any TZIM injection in this round. This temperature profile showed a pronounced inflection in the temperature gradient at approximately $2927 \mathrm{~m}(9600 \mathrm{ft})$, indicating fluid exiting the well bore at that depth. The remaining fluid exited below the depth of the logging run at $3033 \mathrm{~m}(9950 \mathrm{ft})$, as indicated by the relatively cool $176^{\circ} \mathrm{C}$ $\left(348{ }^{\circ} \mathrm{F}\right)$ temperature at the bottom of the log compared to the static temperature of $327^{\circ} \mathrm{C}\left(620^{\circ} \mathrm{F}\right)$. After the injection of the granular TZIM, another temperature survey was run on November 8. This survey, showed a similar profile to the November 17 log, with one zone at approximately $2927 \mathrm{~m}(9600 \mathrm{ft})$ taking fluid and the remaining fluid exiting below $3033 \mathrm{~m}(9950 \mathrm{ft})$. This indicates that the powdered TZIM did not cause significant diversion, probably because the powder size was too small to plug fluid exit points at the well bore.

After the injection of the fibrous TZIM, two more PTS surveys were performed to assess the effectiveness of TZIM injection. A Nov. 19 survey showed that the $2792 \mathrm{~m}(9600 \mathrm{ft})$ zone was taking less fluid (a less pronounced temperature inflection), and that an interval between $2963-2988 \mathrm{~m}(9720-9800 \mathrm{ft})$ began to take fluid as shown by a $22{ }^{\circ} \mathrm{C}\left(40{ }^{\circ} \mathrm{F}\right)$ increase in temperature across this depth interval. In addition, the temperature at the bottom of the $\log$ at $3033 \mathrm{~m}(9950 \mathrm{ft})$ increased to $211^{\circ} \mathrm{C}\left(411^{\circ} \mathrm{F}\right)$ while under continuous injection, indicating that the bottom $15 \mathrm{~m}(50 \mathrm{ft})$ of the hole was no longer being significantly cooled, due to plugging of exit zones in that interval.

Another survey was conducted on November 20 to confirm the observed downhole diversion. The November 20 temperature survey continued to show a reduced flow into the $2927 \mathrm{~m}(9600 \mathrm{ft})$ zone. The cooling observed in a $24 \mathrm{~m}(80 \mathrm{ft})$ interval $12 \mathrm{hours}$ before became more pronounced and localized to $2977 \mathrm{~m}(9766 \mathrm{ft})$ in the November 20 survey, showing cooling at this depth to $150{ }^{\circ} \mathrm{C}(302$ $\left.{ }^{\circ} \mathrm{F}\right)$ lower than the previous three surveys. In addition, the temperature at $3033 \mathrm{~m}(9950 \mathrm{ft})$ reached $226{ }^{\circ} \mathrm{C}\left(440{ }^{\circ} \mathrm{F}\right)$, an temperature increase of almost $38^{\circ} \mathrm{C}\left(100^{\circ} \mathrm{F}\right)$ when compared to the pre-TZIM injecting survey. This indicates that little or no fluid was exiting out of the bottom hole section of the wellbore and that the bottom of the hole was rapidly heating back up to the native, static temperature of $326^{\circ} \mathrm{C}\left(620^{\circ} \mathrm{F}\right)$. Given that there was little to no associated change of flow into the well, this indicates that other fractures within the wellbore must have increased in transmissivity to compensate for the loss of permeable fractures at the bottom of the hole.

\subsubsection{Fall Off}

The well was shut in on October 16, 2014 at 4:30 pm; a PTS tool was set at $1220 \mathrm{~m}$ (4000 ft) while monitoring downhole pressure falloff for 11 hours after shut-in. The pressure fall-off data was used to conduct a Horner analysis in order to estimate the transmissivity of the well. Using first a semi-log analysis approach, the reservoir behavior is anticipated to start after a shut-in time of 4.74 hours. This corresponded to a Horner time of 2.69. Using Equation 3 from Horne (2008),

$$
k=\frac{1.15}{2 \pi} \frac{q \mu}{m h}
$$

the transmissivity $(k h)$ is calculated to be $2.9 \times 10^{-13} \mathrm{~m}^{3}$ using an injection rate of q=0.0083 $\mathrm{m}^{3} / \mathrm{s}(132 \mathrm{gpm})$, viscosity of $1 \mathrm{mPa} / \mathrm{s}$, and a slope of $55 \mathrm{bar} /$ cycle $(5.5 \mathrm{MPa} /$ cycle). . Assuming a reservoir height of $200 \mathrm{~m}$ per stage as presented in Cladouhos et al. (2011), the equivalent permeability is $1.4 \times 10^{-15} \mathrm{~m}^{2}$.

Recording pressure at $1220 \mathrm{~m}(4000 \mathrm{ft}), \sim 1372 \mathrm{~m}(4500 \mathrm{ft})$ above the first exit zone in the wellbore, creates some potential problems. Chief among these issues is that temperature heat up in the wellbore will affect the density of water. The implication of density changes from wellbore heat up is that pressure fall-off at $1220 \mathrm{~m} \mathrm{(4000} \mathrm{ft)} \mathrm{may} \mathrm{occur} \mathrm{at} \mathrm{slower} \mathrm{rate} \mathrm{than} \mathrm{at} 2591 \mathrm{~m}(8500 \mathrm{ft})$.

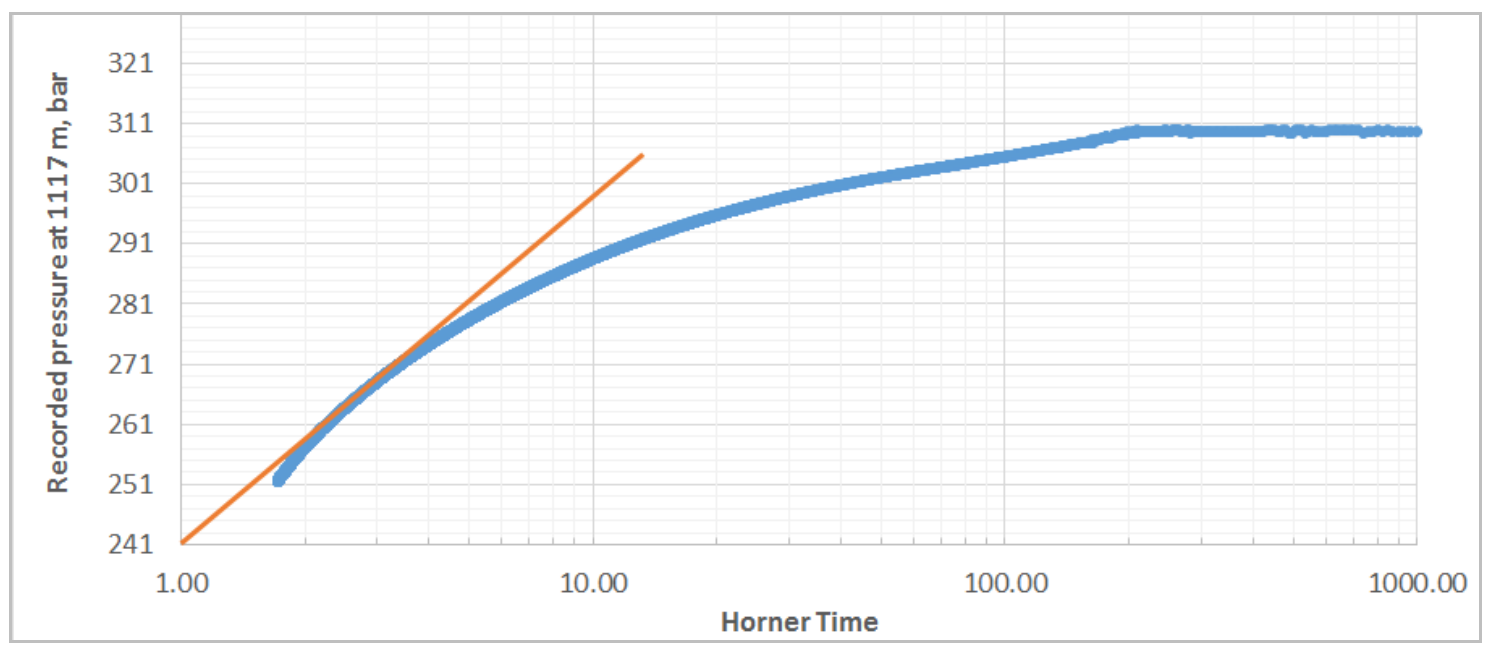

Figure 19: Horner analysis of 55-29 fall-off data at the end of stimulation round 1

\subsubsection{Flowback}

At the end of each round of stimulation the well was shut-in and allowed to heat up before a flow test was conducted. After round 1 stimulation the WHP declined to 69 bar (1000 psi) over 7.5 days from an initial shut-in pressure of 189 bar (2746 psi) before the master 
Cladouhos et al.

valve was opened and the well flowed. After round 2 stimulation the WHP declined to 110 bar (1600 psi) over 3.5 days from an initial shut-in pressure of $187 \mathrm{bar}$ (2715 psi).

The first flow test started at 09:00 on October 23 and lasted for 30 hours. The well began flowing on its own at 9.5 1/s (150 gpm). This initial flow rate declined to about $5.7 \mathrm{l} / \mathrm{s}(90 \mathrm{gpm})$ after an hour. The temperature of flowing water started at $13.8^{\circ} \mathrm{C}\left(57^{\circ} \mathrm{F}\right)$ and quickly rose to $65.6{ }^{\circ} \mathrm{C}\left(150{ }^{\circ} \mathrm{F}\right)$ after 4 hours. As the water temperature approached the boiling temperature for water at the elevation of the wellhead, $93.8^{\circ} \mathrm{C}\left(201^{\circ} \mathrm{F}\right)$, the well began experiencing surging or geysering. The flow was characterized by $4-6$ short periods of high flow 1200-1900 liters (300-500 gallons) per hour followed by long periods with no flow from the well. Thus the average flow was approximately $3.2 \mathrm{l} / \mathrm{s}(50 \mathrm{gpm})$ and the total flow over 30 hours approximately $363 \mathrm{~m}^{3}$ (96,000 gallons).

The second flow test started at 10:00 on November 24 and lasted for 48 hours. The well began flowing on its own at approximately 12.6 1/s (200gpm) because the WHP was higher to start than the first flow test. The same geysering characteristics experienced in the first flow back test were seen when the temperature of the flow back water approached $94{ }^{\circ} \mathrm{C}\left(201^{\circ} \mathrm{F}\right)$. The total flow from the well during the second flow back test was approximately 440,000 liters (116,000 gallons).

Flow back samples were collected downstream of the wellhead for geochemical analysis every 1-3 hours during both flow tests. The two tracers injected during round 2 prior to the two TZIM injections were detected at high concentrations, indicating that the TZIM's at least partially blocked the zones. That is, the TZIMs prevented the tracers from being pushed so far away from the well bore that they would not have been recovered by the relatively small amount of flow back. In addition, break down products of AltaVert 251 were detected in the samples collected on the second day (November 25) of flow back. The TZIM's were injected on Nov 18 and 19 and allowed to heat up starting on November 20. Thermally degradation of AltaVert 251 in about five days at temperatures above $204{ }^{\circ} \mathrm{C}$ $\left(400{ }^{\circ} \mathrm{F}\right)$ is consistent with laboratory testing.

\section{CONCLUSIONS}

During Phase 1, the Newberry project team studied existing data and gathered new regional and well bore data to develop a comprehensive geoscience and reservoir engineering model of the resource underlying the Demonstration site. AltaRock formulated a detailed plan to conduct Phase 2 operations, which includes seismic monitoring, stimulation, drilling and testing. Concurrently, the team assembled a large array of project information to conduct public outreach and inform regulatory agencies. The completed tasks include implementing a public relations campaign by distributing information and determining stakeholder concerns through the use of public meetings, web site and social media and providing detailed project plans and background information to aid the Environmental Assessment and the Phase 1 stage-gate review.

In the fall of 2012, an EGS reservoir was created at Newberry Volcano as evidenced by the cloud of microearthquakes extending 500$800 \mathrm{~m}$ from the injection well. The stimulation occurred at well head pressures between 120 and 167 bar. However, a bimodal distribution of events depths indicated that $\sim 90 \%$ of the seismicity occurred due to a leak in the cased part of the hole. Therefore, the well was repaired at the beginning of the 2014 field season through a casing tie-back to the surface, isolating all casing problems developed in 2012.

In the fall of 2014 , about $9,500 \mathrm{~m}^{3}$ (2.5 million gallons) of ground water was injected during a total of 4 weeks of hydraulic stimulation. Well head pressures greater than 165 bar (2450 psi) were required to improve injectivity of the well, which was significantly higher than expected. A permanent injectivity improvement from 0.009-0.045 (1/s)/bar $(0.01-0.05 \mathrm{gpm} / \mathrm{psi})$ was achieved. However, much of the stimulation was run near the limits of the pumps, well head, surface piping and permits, limiting the ability to further improve injectivity. For future stimulations at Newberry, AltaRock will modify the stimulation pumps to be able to stimulate at higher pressures.

TZIM was injected near the end of the second round of stimulation. Temperature logs run before, during and after injection of a fibrous form of AltaVert 251 showed that at least two flow zones were blocked and one or two new zones opened due to the diverter. The fibrous form of TZIM was found to be more effective at blocking permeable zones than the particulate TZIM. Break-down products of TZIM were detected in flow-back fluids, indicating that the material degraded as predicted.

During the 2014 stimulation, locations for 398 microseismic events were determined using the MSA installed in 2012. Event locations determined by different methods define an EGS reservoir that extends at least $200 \mathrm{~m}$ (656 ft) from the well bore. Further work has been conducted that uses microseismic data in conjunction with well log data, as well as moment tensor data, to design an optimal well path for a second well at Newberry. This second well has been planned to be drilled in the summer of 2015. This newly drilled well will be stimulated and the lessons learned from the previous stimulations will be applied for maximum success. For more information regarding well targeting analysis please refer to (Cladouhos T. T. et al, 2015).

\section{Acknowledgment}

This material is based on work supported by the Department of Energy under Award Number DE-EE0002777.

\section{Disclaimer}

This paper was prepared as an account of work sponsored by an agency of the United States Government. Neither the United States Government nor any agency thereof, nor any of their employees, makes any warranty, express or implied, or assumes any legal liability or responsibility for the accuracy, completeness, or usefulness of any information, apparatus, product, or process disclosed, or represents that its use would not infringe privately owned rights. Reference herein to any specific commercial product, process, or service by trade name, trademark, manufacturer, or otherwise does not necessarily constitute or imply its endorsement, recommendation, or favoring by 
the United States Government or any agency thereof. The views and opinions of authors expressed herein do not necessarily state or reflect those of the United States Government or any agency thereof.

\section{Intellectual property statement}

AltaRock holds a portfolio of patents, patent applications, licenses and related proprietary intellectual property regarding its thermallydegradable zonal isolation materials, TZIM, and stimulation technology, materials and methods.

\section{REFERENCES}

AltaRock, Newberry EGS Demonstration Induced Seismicity Mitigation Plan, 64 pp. plus 14 appendices. Available at: http://www.altarockenergy.com/projectupdates/Newberry_ISMPlan.pdf (2011).

BLM, Newberry Volcano Enhanced Geothermal System (EGS) Demonstration Project, Environmental Assessment, 148 pp. plus 2 appendices, Available at http://www.blm.gov/or/districts/prineville/plans/newberryegs/index.php. (2011).

Cladouhos, T.T., Uddenberg, M., Swyer, M.W., Petty, S., and Nordin, Y.: Production Well Targeting at Newberry Volcano EGS Demonstration, GRC Transactions, 39, (2015).

Cladouhos, T.T., Swyer, M.W., Uddenberg, M., and Petty, S., Results from Newberry Volcano EGS Demonstration, Proceedings, 40th Workshop on Geothermal Reservoir Engineering Stanford University, Stanford, CA, (2015)

Cladouhos, T.T., Petty, S., Nordin, Y., Moore, M., Grasso, K., Uddenberg, M., Swyer, M., Julian, B., and Foulger, G. Microseismic Monitoring of Newberry Volcano EGS Demonstration, Proceedings, 38th Workshop on Geothermal Reservoir Engineering Stanford University, Stanford, CA, (2013a).

Cladouhos, T.T., Petty, S., Nordin, Y., Moore, M., Grasso, K., Uddenberg, M. and Swyer, M.W. Stimulation Results from the Newberry Volcano EGS Demonstration, GRC Transactions, 37, (2013b) 133-140.

Cladouhos, T.T., Osborn, W.L., and Petty, S., Newberry Volcano EGS Demonstration-Phase I Results, Proceedings, 37th Workshop on Geothermal Reservoir Engineering Stanford University, Stanford, CA (2012).

Cladouhos, T.T., M. Clyne, M. Nichols, S. Petty, W.L. Osborn, and L. Nofziger. Newberry Volcano EGS Demonstration Stimulation Modeling, GRC Transactions, 35, (2011b) 317-322.

Cladouhos, T.T., Petty, S., Callahan, O., Osborn, W, Hickman, S. and Davatzes, N. The Role of Stress Modeling in Stimulation Planning at the Newberry Volcano EGS Demonstration Project, Proceedings: Thirty-Sixth Workshop on Geothermal Reservoir Engineering, Stanford University, Stanford, California, January 31-February 2, (2011a), SGP-TR-1191, 630-637.

Davatzes N. C. and S. H. Hickman: Preliminary Analysis of Stress in the Newberry EGS Well NWG 55-29, GRC transactions, 35, 323$332,2011$.

Julian, B.R. and G.R. Foulger, Microearthquake focal mechanisms - A tool for monitoring geothermal systems, Geotherm. Res. Council Bull., 33, (2004) 166-171.

Horne, R.N., Modern Well Test Analysis pg. 54-61. (2008).

Kim J., Sonnenthal, E., and Rutqvist, J.: Formulation and Sequential Numerical Algorithms of Coupled Fluid/Heat Flow and Geomechanics for Multiple Porosity Materials, International Journal of Numerical Methods in Engineering, 92, (2012), $425-456$.

Kim J., Sonnenthal, E., and Rutqvist, J.: A Sequential Implicit Algorithm of Chemo-Thermo-Poro-Mechanics for Fractured Geothermal Reservoirs, Computers \& Geosciences, 76, (2015), 59-71.

LBNL, http://esd.lbl.gov/research/projects/induced_seismicity/egs/newberry.html (2015).

Majer, E., Baria, R., Stark, M. Protocol for induced seismicity associated with enhanced geothermal systems. Report produced in Task D Annex I (9 April 2008), International Energy Agency - Geothermal Implementing Agreement (Incorporating comments by: C. Bromley, W. Cumming, A. Jelacic and L. Rybach). Available at: http://iea-gia.org/wp-content/uploads/2014/01/Protocol-forInduced-Seismicity-EGS_GIA-Doc-25Feb09-ed9Mar10.pdf (2008).

Majer, E. J., Robertson-Tait, N.A., Savy, J., Wong, I. Protocol for Addressing Induced Seismicity Associated with Enhanced Geothermal Systems (EGS). Available at: http://esd.lbl.gov/files/research/projects/induced_seismicity/egs/EGS-IS-Protocol-Final-Draft-20110531.pdf. (2011).

McGarr, A. Maximum magnitude earthquakes induced by fluid injection. Journal of Geophysical Research: Solid Earth, (2014) 119.

Osborn, W.L., Petty, S., Cladouhos, T.T., Iovenitti, J., Nofziger, L., Callahan, O., Perry, D.S. and Stern P.L. Newberry Volcano EGS Demonstration - Phase I Results, GRC Transactions, 35, (2011) 499-505.

Osborn, W., Petty, S., Nofziger, L. and Perry, D. Newberry Volcano EGS Demonstration Geothermal Resources Council Transactions, 34, (2010) 413-418.

Parotidis, M., Shapiro, S.A., Rothert, E. Back front of seismicity induced after termination of borehole fluid injection. Geophysical Research Letters, 31, L02612 (2004). 
Cladouhos et al.

Petty, S. Nordin, Y., Glassely, W. and Cladouhos, T. Improving Geothermal Project Economics with Multi-zone Stimulation: Results from the Newberry Volcano EGS Demonstration, Proceedings, 38th Workshop on Geothermal Reservoir Engineering Stanford University, Stanford, CA, (2013).

PNSN, http://pnsn.org/volcanoes/newberry (2015).

Rinaldi, A.P., Rutqvist, J., Sonnenthal, E.L. and Cladouhos, T.T.: Coupled THM modeling of hydroshearing stimulation in tight fractured volcanic rock, Transport in Porous Media, (2014), doi:10.1007/s11242-014-0296-5.

Roeloffs, E. Advances in Geophysics. Academic Press, San Diego, CA. v. 37 (1996).

Shapiro, S. A., C. Dinske, C. Lagenbruch, and F. Wenzel. Seismogenic index and magnitude probability of earthquakes induced during reservoir fluid stimulations, The Leading Edge, (March 2010), 304-309.

Shapiro, S. A., and C. Dinske. Scaling of seismicity induced by nonlinear fluid-rock interaction, J.Geophys. Res.,114, B09307, doi:10.1029/2008JB006145 (2009).

Sonnenthal, Eric L., Torquil Smith, J., Cladouhos, T. and Kim, J. Thermal-Hydrological-Mechanical-Chemical Modeling of the 2014 EGS Stimulation Experiment at Newberry Volcano, Oregon, Proceedings, Fourtieth Workshop on Geothermal Reservoir Engineering, Stanford University, Stanford, California, (2015).

Sonnenthal, E. L., Spycher, N., Callahan, O., Cladouhos, T., and Petty, S.: A Thermal-Hydrological-Chemical Model for the Enhanced Geothermal System Demonstration Project at Newberry Volcano, Oregon, Proceedings, 37th Workshop On Geothermal Reservoir Engineering, Stanford University, Stanford, CA, (2012).

Xu, T., Spycher, N., Sonnenthal, E., Zhang, G., Zheng, L., and Pruess, K.: TOUGHREACT Version 2.0: A Simulator for Subsurface Reactive Transport Under Non-Isothermal Multiphase Flow Conditions, Computers \& Geosciences, 37, (2011), 763-774. 